\title{
Laboratory measurements of nitric oxide release from forest soil with a thick organic layer under different understory types
}

\author{
A. Bargsten ${ }^{1}$, E. Falge ${ }^{1}$, K. Pritsch ${ }^{2}$, B. Huwe ${ }^{3}$, and F. X. Meixner ${ }^{1,4}$ \\ ${ }^{1}$ Biogeochemistry Department, Max Planck Institute of Chemistry, 55020 Mainz, Germany \\ ${ }^{2}$ Institute of Soil Ecology, German Research Center for Environmental Health, Helmholtz Zentrum München, \\ Neuherberg, Germany \\ ${ }^{3}$ Soil Physics Department, University of Bayreuth, Germany \\ ${ }^{4}$ Physics Department, University of Zimbabwe, Harare, Zimbabwe
}

Received: 17 December 2009 - Published in Biogeosciences Discuss.: 13 January 2010

Revised: 22 April 2010 - Accepted: 26 April 2010 - Published: 6 May 2010

\begin{abstract}
Nitric oxide (NO) plays an important role in the photochemistry of the troposphere. NO from soil contributes up to $40 \%$ to the global budget of atmospheric NO. Soil NO emissions are primarily caused by biological activity (nitrification and denitrification), that occurs in the uppermost centimeter of the soil, a soil region often characterized by high contents of organic material. Most studies of NO emission potentials to date have investigated mineral soil layers. In our study we sampled soil organic matter under different understories (moss, grass, spruce and blueberries) in a humid mountainous Norway spruce forest plantation in the Fichtelgebirge (Germany). We performed laboratory incubation and flushing experiments using a customized chamber technique to determine the response of net potential NO flux to physical and chemical soil conditions (water content and temperature, bulk density, particle density, $\mathrm{pH}, \mathrm{C} / \mathrm{N}$ ratio, organic $\mathrm{C}$, soil ammonium, soil nitrate). Net potential NO fluxes (in terms of mass of $\mathrm{N}$ ) from soil samples taken under different understories ranged from 1.7-9.8 $\mathrm{ng} \mathrm{m}^{-2} \mathrm{~s}^{-1}$ (soil sampled under grass and moss cover), 55.4-59.3 $\mathrm{ng} \mathrm{m}^{-2} \mathrm{~s}^{-1}$ (soil sampled under spruce cover), and $43.7-114.6 \mathrm{ng} \mathrm{m}^{-2} \mathrm{~s}^{-1}$ (soil sampled under blueberry cover) at optimum water content and a soil temperature of $10^{\circ} \mathrm{C}$. The water content for optimum net potential NO flux ranged between 0.76 and 0.8 gravimetric soil moisture for moss covered soils, between 1.0 and 1.1 for grass covered soils, 1.1 and 1.2 for spruce covered soils, and 1.3 and 1.9 for blueberry covered soils. Effects of soil physical and chemical characteristics on net poten-
\end{abstract}

Correspondence to: A. Bargsten (anika.bargsten@mpic.de) tial NO flux were statistically significant $(0.01$ probability level) only for $\mathrm{NH}_{4}^{+}$. Therefore, as an alternative explanation for the differences in soil biogenic NO emission we consider more biological factors like understory vegetation type, amount of roots, and degree of mycorrhization; they have the potential to explain the observed differences of net potential NO fluxes.

\section{Introduction}

Nitric oxide (NO) is a reactive gas which plays a central role in the photochemistry of the troposphere (Crutzen, 1979). The photochemistry of $\mathrm{NO}$ and nitrogen dioxide $\left(\mathrm{NO}_{2}\right)$ is important for the generation/destruction of tropospheric ozone and, hence, regulates the oxidizing capacity of the troposphere. The oxidation products of $\mathrm{NO}$ (gaseous $\mathrm{NO}_{2}$, nitrous and nitric acid, particulate nitrite and nitrate) also contribute to the generation of acid rain (Crutzen, 1979) affecting human health and plant productivity.

With respect to NO biosphere-atmosphere exchange, soils are of great interest due to the fact that NO biogenic emissions from soil contribute up to $40 \%$ to the global budget of atmospheric NO (Davidson and Kingerlee, 1997; Meixner, 1994; Denman et al., 2007; Rudolph and Conrad, 1996). Kesik et al. (2005) predicted that by 2039 soil NO emissions will increase by $9 \%$. Soils have the potential for acting as a sink for atmospheric NO (Conrad, 1994). Only a few studies provide an indication of soils acting as a sink (Dunfield and Knowles, 1998; Skiba et al., 1994; Slemr and Seiler, 1991). The NO flux between soil and atmosphere is a result of microbial consumption and production of NO in the top

Published by Copernicus Publications on behalf of the European Geosciences Union. 
soil layer. NO production and consumption occur simultaneously during nitrification and denitrification (Remde et al., 1989; Rudolph and Conrad, 1996; Skiba et al., 1997; Firestone and Davidson, 1989). In both soil microbial processes NO can be an intermediate, it can be released and also absorbed (Galbally, 1989).

In most cases the organic layer is the only soil layer in direct contact with the atmosphere. There are soils having an organic layer with a thickness of $10 \mathrm{~cm}$ or more; these thick organic layers are mostly a kind of moder or raw humus (Scheffer and Schachtschabel, 2002). Mineral soils under these organic layers are never in contact with the atmosphere. Hence, as shown by Gasche and Papen (1999), who examined soils under a spruce canopy, the most important layer for NO exchange is the uppermost organic layer. In their experiment with intact soil cores from a spruce forest site they found that the organic layer contributed over $86 \%$ to the NO emission from soil. It is also known that nitrification occurs predominantly in the first few centimeters of soils (Papke and Papen, 1998; Rudolph and Conrad, 1996; Laville et al., 2009; Venterea et al., 2005; Remde et al., 1993; Jambert et al., 1994). Venterea et al. (2005) found actually the highest NO production in the first centimeter. Organic soils support high nitrification and denitrification rates and may be important hot spots of NO emission (Guthrie and Duxbury, 1978). Denitrification, in contrast, normally occurs in deeper soil layers or in the water table. In this respect, the role of organic matter is potentially important (Jambert et al., 1994).

In forests the type of understory influences NO exchange between the soil and the trunk space (Jambert et al., 1994; Pilegaard et al., 1999). Most studies to date have focused on the influence of the overstory vegetation and/or soil nutrients (Fowler et al., 2009; Venterea et al., 2004; Pilegaard et al., 2006). As reported by Oberdorfer (1994), Norway spruce forests fall into a series of plant sociological associations, which are characterized by the main understory species present (e.g. Calamagrostio villosae - Piceetum). Within one individual forest stand the understory might be composed of patches characterized by different species (e.g. Calamagrostis villosa, Vaccinium myrtillus, Deschampsia flexuosa). There are only a few studies how plants influence the NO exchange between soil and atmosphere (Stöhr and Stremlau, 2006; Stöhr and Ullrich, 2002), and there is a considerable lack of knowledge in this area.

To investigate the effect of soil physical and chemical parameters and understory types on $\mathrm{NO}$ emission from thick organic layers of forest soils we carried out laboratory incubation and flushing experiments on soils sampled below various understory covers in a Norway spruce forest in south-eastern Germany.

\section{Material and methods}

\subsection{Sample site}

The field site is located at Weidenbrunnen $\left(50^{\circ} 09^{\prime} \mathrm{N}\right.$, $11^{\circ} 34^{\prime} \mathrm{E}, 774 \mathrm{~m}$ above sea level) which is situated in the Fichtelgebirge Mountains, NE Bavaria, Germany. The site is mainly covered by 55-year-old Norway spruce (Picea abies) with significant variability in the understory. There are four different main understory types: moss, grass (Deschampsia flexuosa and Calamagrostis villosa), blueberries (Vaccinium myrtillus), and young spruce which cover 45, 19, 7 and 13\%, respectively, of the total surface area of the Weidenbrunnen site (Behrendt, 2009). Mean annual air temperature of the Weidenbrunnen site is $5.3^{\circ} \mathrm{C}$, mean annual soil temperature is $6.3^{\circ} \mathrm{C}$, and mean annual precipitation is approximately $1160 \mathrm{~mm}$ (1971-2000; Foken, 2003; Falge et al., 2003). The soil type was classified as cambic podzol over granite (Subke et al., 2003), and the texture is sandy loam to loam, with relatively high clay content in the $\mathrm{Bh}$ horizon. The mineral soil is characterised by low $\mathrm{pH}$ values $(<4)$. The soil litter and the organic horizon had a thickness between 5 and $9 \mathrm{~cm}$ (Behrendt, 2009). The organic layer is classified as a moder consisting of Oi, Oe, and Oa horizons. More details concerning the site can be found in Gerstberger et al. (2004).

\subsection{Soil sampling and preparation}

In September 2008, soil samples for the laboratory study on NO release were taken from the $\mathrm{O}$ horizon at patches below the main understory types: moss, grass, young spruce, and blueberries. An individual understory patch has been defined, such that one square meter of understory area has to be covered mainly $(>50 \%)$ with the respective understory vegetation. Two samples were taken for each understory type, resulting in a total of eight soil samples (soil samples taken under moss: M1, M2, soil samples taken under grass: G1, G2, soil samples taken under spruce: S1, S2, soil samples taken under blueberries: B1, B2). The soil samples were air dried and then stored at $4{ }^{\circ} \mathrm{C}$ until analysis. All measurements were performed within 2 months after sampling.

For our laboratory studies of NO release rates, samples were sieved through a $16 \mathrm{~mm}$ mesh to homogenise the soil and, all green biomass was removed. This can be contrasted with previous studies of mineral soils and sands where samples were sieved through $2 \mathrm{~mm}$ mesh (van Dijk and Meixner, 2001; van Dijk et al., 2002; Feig et al., 2008; Yu et al., 2008; Gelfand et al., 2009). A $16 \mathrm{~mm}$ mesh was chosen, based on tests sieving Weidenbrunnen organic matter through 2, 4, 8, and $16 \mathrm{~mm}$ mesh sizes. These experiments showed, that sieving through a $2 \mathrm{~mm}$ mesh destroyed the structure of soil organic matter causing higher NO release rates than observed when sieving through 4,8 and $16 \mathrm{~mm}$ meshes whose corresponding NO release rates were not significantly different from each other (see Fig. 1). 


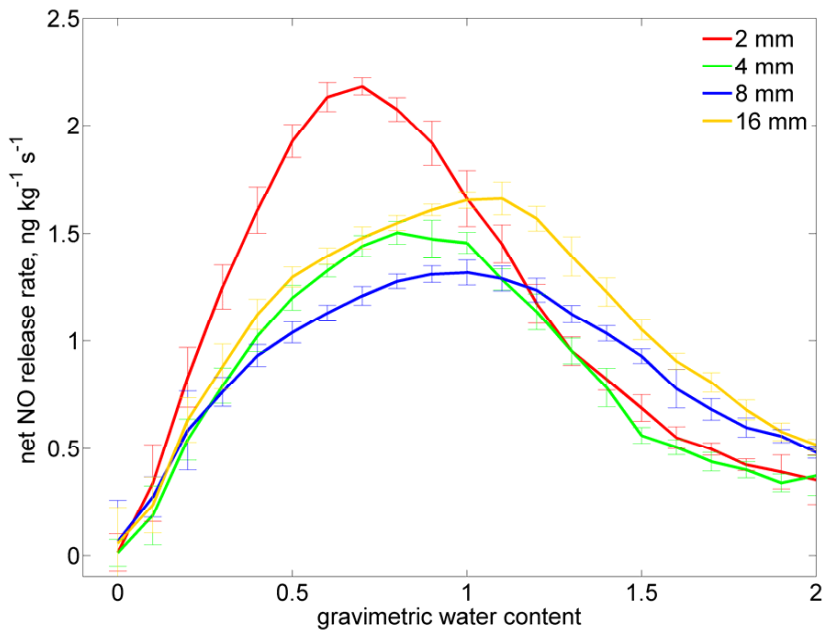

Fig. 1. The effect of sieving organic soil samples through sieves of different mesh sizes on the observed net NO release rates $\left(T_{\text {soil }}=10^{\circ} \mathrm{C}\right)$. Error bars show the standard deviation of the net NO release rate (expressed in terms of mass of nitrogen) averaged over bins of 0.1 gravimetric soil moisture.

For measurements of net NO release rates approx. $0.1 \mathrm{~kg}$ soil was placed into a Plexiglas cuvette, wetted with deionised water to a gravimetric water content $>3$ (using a spray can) and pre-incubated for 3 hours in a thermoregulated cabinet to adapt to the soil temperature used during the corresponding NO release experiments. Former experiments showed that net NO release rates increase fairly proportionally with soil mass in the chambers up to $100 \mathrm{~g}$, after which the slope declines. This indicates that from this soil mass onwards gas diffusion through the soil could be limiting. These results are similar to those of Remde et al. (1989) where the NO flux rate was shown to be proportional to the soil mass in the chamber up to $150 \mathrm{~g}$. Above $150 \mathrm{~g}$ the relationship between NO flux and soil mass was no longer linear.

\subsection{Soil physical and chemical characterization}

In addition to samples for use in flux measurements, we took organic layer samples from each understory patch for the determination of soil $\mathrm{pH}, \mathrm{C} / \mathrm{N}$ ratio, organic $\mathrm{C}\left(\mathrm{C}_{\mathrm{org}}\right)$, soil nitrate $\left(\mathrm{NO}_{3}^{-}\right)$, soil ammonium $\left(\mathrm{NH}_{4}^{+}\right)$, bulk density $(\mathrm{BD})$ and particle density (PD).

For the determination of soil $\mathrm{pH}$ the organic matter was homogenized and afterwards measured in a soil-to-water suspension (1:2.5) using a glass electrode (SenTix ${ }^{\circledR}$, WTW, Germany). The $\mathrm{C} / \mathrm{N}$ ratio was measured with an elementary analyzer (Flash EA 1112, Thermoquest, Germany). $\mathrm{C}_{\text {org }}$ was determined by the mean difference of $5 \mathrm{~g}$ (air dried) of the soil sample and $5 \mathrm{~g}$ dried at $430{ }^{\circ} \mathrm{C}$ in a muffle furnace (until constant weight was achieved). The ammonium and nitrate concentrations in extracts of the soil samples were measured by spectrometry (FIA-lab, MLE, Germany). For

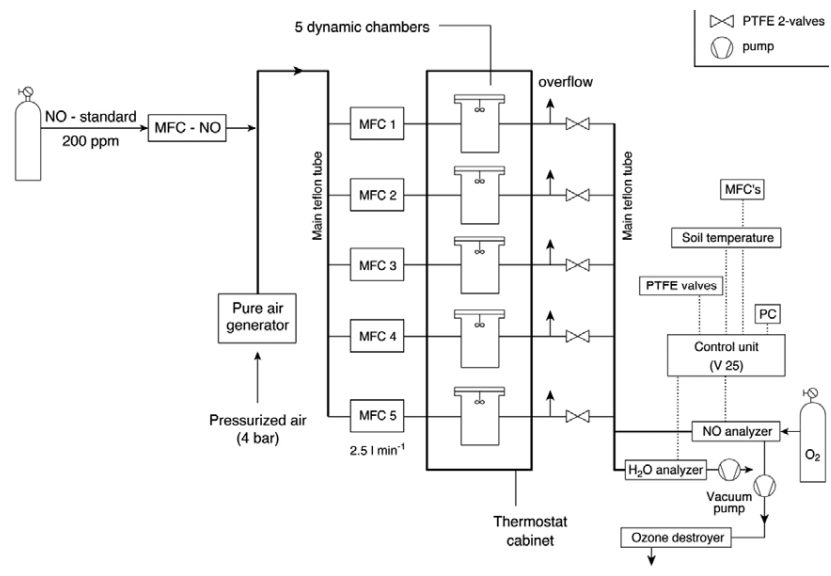

Fig. 2. Experimental setup for laboratory investigation of net NO release rates on soil samples (details, see Sect. 2.4).

determination of the soil bulk density, undisturbed soil samples were taken using a spade and afterwards dimensioned. Then the samples were dried at $60^{\circ} \mathrm{C}$ for $24 \mathrm{~h}$. From each patch we took three soil cores and individual quantities were averaged over these. Particle density of the soil sample was determined by a heliumpycnometer (AccuPyc II 1340, Micromeritics, USA) after sieving soil samples through a $2 \mathrm{~mm}$ mesh.

\subsection{Laboratory setup}

Net NO release rates from soil samples were determined using an automated laboratory system. A detailed description of our experimental setup is given in van Dijk and Meixner (2001); here we give only a short description of the most recent state of the setup (see Fig. 2).

Pressurized air is passed through a pure air generator (PAG 003, ECOPHYSICS, Switzerland) to provide dry and NOfree air. This NO-free air supplied five Plexiglas cuvettes (four incubation cuvettes and one empty reference cuvette). The volume of each cuvette was $9.7 \times 10^{-4} \mathrm{~m}^{3}(0.971)$ ) and each was flushed with a continuous flow of $4.2 \times 10^{-5} \mathrm{~m}^{3} \mathrm{~s}^{-1}$ $\left(2.51 \mathrm{~min}^{-1}\right)$ of dry NO-free air, as controlled by five mass flow controllers (MFC, Mass-Flo, $5000 \mathrm{sccm}$ range, MKS instruments, USA), one for each cuvette. The headspace volume of each cuvette is well mixed by a teflonized microfan (Micronel®, USA). The outlet of each cuvette was connected to a switching valve. Every two minutes one cuvette was switched to be the "active" cuvette (i.e., connected to the analyzers, while the remaining four cuvettes were still purged), so that all five cuvettes were measured within $10 \mathrm{~min}$. The valves provided necessary sample air to a chemiluminescence detector, NO-analyser (Model 42i Trace Level, Thermo Electron Corporation, USA; detection limit: $250 \mathrm{ppt}$ $(3 \sigma)$ ) and a $\mathrm{CO}_{2}-/ \mathrm{H}_{2} \mathrm{O}$-analyzer (Li-cor 840 , Licor, USA). Instead of ambient air we operated the NO-analyser with pure oxygen $\left(\mathrm{O}_{2}\right)$ to obtain a better accuracy and precision of 
the NO mixing ratio measurements, particularly at low mixing ratios.

The NO-analyser was calibrated using a gas phase titration unit (GPT, 146 C Dynamic Gas Calibrator, Thermo Electron Corporation, USA). For operating the GPT we used NO-free air from the PAG 003 and an NO gas standard (5.02 ppm NO, Air Liquide, Germany). The determination of the soil NO compensation mixing ratio (Conrad, 1994) requires the flushing of incubated soil samples with enhanced NO mixing ratios (resulting in reduced or even negative net $\mathrm{NO}$ release rates, i.e. NO uptake by the soil). Hence, NO standard gas (200 ppm NO, Air Liquide, Germany) was diluted into the air flow from the PAG 003 via a mass flow controller (Flow EL, Bronkhorst, Germany).

All connections and tubes consisted of polytetrafluorethylene (PTFE). A homebuilt control unit (V25) was controlling the entire laboratory system and, in combination with a computer, was also used for data acquisition (see Fig. 2).

To determine the temperature response of the net NO release we performed a total of four experiments, each on another sub-sample of the original understory soil sample. The sub-samples were identically pre-treated. Incubations were at $10^{\circ} \mathrm{C}$ and $20^{\circ} \mathrm{C}$, corresponding flushing was either with dry, NO-free air, or with air containing $133 \mathrm{ppb}$ of NO. Since every experiment begins with a wetted soil sample and the flushing air is completely dry, the gravimetric water content $(\theta)$ of the samples declines during each experiment as evaporating water leaves the cuvette with the flushing air flow. Gravimetric soil moisture content was measured by tracking the loss of water vapour throughout the measurement period and relating this temporal integral to the gravimetric soil moisture content observed at the start and end of the measurement period. Soil samples are completely dry within 4 to 7 days. This procedure provides us the response of the net NO release rates over the entire range of gravimetric soil moisture ( $>4$ to 0 ). Gravimetric soil moisture ranging from 0 to 4 corresponds to a water filled pore space (WFPS) from 0 to 0.7 .

The NO release rate is a product of NO consumption and NO production, because both processes occur simultaneously in the topsoil (Rudolph and Conrad, 1996; Conrad, 1994). Consequently, the observed NO release rate, J (see Eq. 1), is always a net release rate. If NO consumption overrides the NO production in the soil sample, then $\mathrm{J}$ becomes negative. However, this only occurs if the the NO mixing ratio in the reference cuvette, $m_{\mathrm{NO}}$,ref, exceeds the NO mixing ratio in the headspace of a sample cuvette (which is equal to the corresponding outlet $\mathrm{NO}$ mixing ratio, $m_{\mathrm{NO}}$, out, due to well-mixed conditions within each sample cuvette).

\subsection{Calculation and fitting the net NO release rate}

For a given constant incubation temperature $\left(10^{\circ} \mathrm{C}, 20^{\circ} \mathrm{C}\right)$ we derived from our laboratory data the net $\mathrm{NO}$ release rate $J=J(\theta)$ (in ng NO (in terms of mass of nitrogen) per mass of (dry) soil (kg) and time (s)) as a function of the gravimetric soil moisture $(\theta)$ of the soil samples. $J(\theta)$ was calculated from the NO mixing ratio difference between the reference cuvette $\left(m_{\mathrm{NO}, \mathrm{ref}}\right.$, in $\left.\mathrm{ppb}\right)$ and the soil incubation $\mathrm{cu}-$ vettes $\left(m_{\mathrm{NO}, \text { out }}\right.$, in $\left.\mathrm{ppb}\right)$ :

$J(\theta)=\frac{Q}{M_{\text {soil }}}\left(m_{\mathrm{NO}, \text { out }}-m_{\mathrm{NO}, \mathrm{ref}}\right) \cdot \frac{M_{N}}{V_{m}} \times 10^{-3}$

where $Q$ is the flow through the cuvette $\left(\mathrm{m}^{3} \mathrm{~s}^{-1}\right), \mathrm{M}_{\text {soil }}$ is the dry mass of the soil sample $(\mathrm{kg}), \mathrm{M}_{N} / \mathrm{V}_{m} \cdot 10^{-3}$ is the conversion factor (ppb to $\mathrm{ng} \mathrm{m}^{-3}$ ), where $\mathrm{M}_{N}$ is the molecular weight of nitrogen $\left(14.0076 \mathrm{~kg} \mathrm{kmol}^{-1}\right)$ and $\mathrm{V}_{m}$ is the molar volume $\left(\mathrm{m}^{3} \mathrm{kmol}^{-1}\right)$ at actual temperature and standard pressure (1013.25 $\mathrm{hPa})$.

Individual data of measured net NO release rates were fitted with a 3 parameter function (Eq. 2) modified from that given by Meixner and Yang (2006) in order to yield two of the three parameters as measured quantities $\left(\theta_{\mathrm{opt}}, J_{\mathrm{opt}}\right)$ :

$J(\theta)=J_{\mathrm{opt}} \cdot\left(\frac{\theta}{\theta_{\mathrm{opt}}}\right)^{b} \cdot \exp \left(b\left(1-\frac{\theta}{\theta_{\mathrm{opt}}}\right)\right)$

where $\theta_{\text {opt }}$ is the gravimetric water content where the optimum net NO release rate $\left(J_{\text {opt }}:=J\left(\theta_{\text {opt }}\right)\right)$ is observed, and $b$ characterizes the width of the fitting curve. The gnuplot ${ }^{\circledR}$ software (www.gnuplot.info, see copyright information) was used for fitting.

It has been frequently shown, that there is a linear relationship between the net NO release rate $(J)$ and the headspace NO mixing ratio ( $m_{\mathrm{NO} \text {,out }}$ ) (Remde et al., 1989; van Dijk and Meixner, 2001; van Dijk et al., 2002; Ludwig et al., 2001):

$J=P-K=P-k \cdot m_{\mathrm{NO}, \text { out }} \cdot \frac{M_{N}}{V_{m}} \times 10^{-3}$

Equation (3) implies that the NO production rate $P$ ( $\mathrm{ng} \mathrm{kg}^{-1} \mathrm{~s}^{-1}$ ) is independent of the cuvette's headspace NO mixing ratio $\left(m_{\mathrm{NO}, \text { out }}\right)$, whereas the first-order NO consumption rate, $K\left(\mathrm{ng} \mathrm{kg}^{-1} \mathrm{~s}^{-1}\right)$, is dependent on it. The NO consumption coefficient $k\left(\mathrm{~m}^{3} \mathrm{~kg}^{-1} \mathrm{~s}^{-1}\right)$ is determined from the slope of Eq. (3). To obtain this slope, we used two incubation data sets: namely at $m_{\mathrm{NO}, \text { ref }}=0 \mathrm{ppb}$ and $m_{\mathrm{NO} \text {, ref }}=133 \mathrm{ppb}$,

$k(\theta)=$

$\frac{\Delta J_{\mathrm{NO}}}{\Delta[\mathrm{NO}]}-\frac{J\left(m_{\mathrm{NO}, \text { out }, \text { high }}\right)-J\left(m_{\mathrm{NO}, \text { out }, \text { low }}\right)}{m_{\mathrm{NO}, \text { out }, \text { high }}-m_{\mathrm{NO}, \text { out }, \text { low }}} \cdot \frac{V_{m}}{M_{N}} \times 10^{-3}$

where $m_{\mathrm{NO} \text {,out, low }}$ is the actual NO mixing ratio (ppb) in the headspace of the cuvette under flushing with NO free air and $m_{\mathrm{NO}}$,out,high is the actual $\mathrm{NO}$ mixing ratio in the cuvette under flushing with $133 \mathrm{ppb}$ NO. Having determined k, the NO production rate $\mathrm{P}$ was calculated from Eq. (3) and corresponding NO net release rates $\mathrm{J}$ from Eq. (1).

Finally, Eq. (3) is extended to describe the net NO release rate, for each soil sample, as a function of the main influencing variables, headspace $\mathrm{NO}$ mixing ratio $\left(m_{\mathrm{NO}}\right.$, out $)$, gravimetric water content $(\theta)$ and soil temperature $\left(T_{\text {soil }}\right)$. For 
the temperature dependence we used the $\mathrm{Q}_{10}$ values (see Sect. 2.8), as a "temperature amplification factor" (Feig et al., 2008):

$$
\begin{aligned}
& J\left(m_{\mathrm{NO}, \text { out }}, \theta, T_{P} \text { soil }\right)= \\
& P\left(\theta, T_{\text {soil }}\right)-k\left(\theta, T_{\text {soil }}\right) \cdot m_{\mathrm{NO}, \text { out }} \cdot \frac{M_{N}}{V_{m}} \times 10^{-3}
\end{aligned}
$$

\subsection{NO compensation point mixing ratio}

The existence of a NO compensation point mixing ratio $\left(m_{\text {NO,comp }}\right)$ has been clearly demonstrated (Remde et al., 1989; van Dijk and Meixner, 2001; Conrad, 1994; Gelfand et al., 2009; Feig et al., 2008; Otter et al., 1999; Johansson and Granat, 1984). Considering Eq. (5) $m_{\mathrm{NO} \text {,comp }}$ is the mixing ratio $\left(m_{\mathrm{NO} \text {,out }}\right)$ at which the rate of $\mathrm{NO}$ production $\mathrm{P}$ equals the rate of $\mathrm{NO}$ consumption $\mathrm{K}$, so that the net $\mathrm{NO}$ release rate between soil and the headspace is zero $(J=0)$. Hence, from Eq. (6) $m_{\mathrm{NO}}$,comp is calculated in terms of gravimetric soil water content and soil temperature.

$m_{\mathrm{NO}, \mathrm{comp}}\left(\theta, T_{\text {soil }}\right)=\frac{P\left(\theta, T_{\text {soil }}\right)}{k\left(\theta, T_{\text {soil }}\right)} \cdot \frac{V_{m}}{M_{N}} \times 10^{-3}$

\subsection{Net potential NO flux}

To relate the net NO release rate, which is expressed in ng NO per mass of soil and time, to the net potential NO flux, which is expressed in ng NO per soil area and time, we used the following equation, originally presented by Galbally and Johansson (1989), which has been used in modified forms already by Otter et al. (1999), van Dijk and Meixner (2001), Feig et al. (2008), Gelfand (2009), Yu et al. (2008).

$$
\begin{aligned}
F_{\mathrm{NO}}\left(\theta, T_{\text {soil }}\right)= & \sqrt{D_{p}(\theta) \cdot B D \cdot k\left(\theta, T_{\text {soil }}\right)} \\
& \cdot\left(\frac{P\left(\theta, T_{\text {soil }}\right)}{k\left(\theta, T_{\text {soil }}\right)}-m_{\mathrm{NO}, \text { out }} \cdot \frac{M_{N}}{V_{m}} \times 10^{-3}\right)
\end{aligned}
$$

$F_{\mathrm{NO}}$ is the desired net potential NO flux $\left(\mathrm{ng} \mathrm{m}^{-2} \mathrm{~s}^{-1}\right)$, $\mathrm{BD}$ is the bulk density of soil $\left(\mathrm{kg} \mathrm{m}^{-3}\right), \mathrm{D}_{p}$ is the effective diffusion coefficient of $\mathrm{NO}$ in soil (in $\mathrm{m}^{2} \mathrm{~s}^{-1}$ ) according to Millington and Quirk (1960) (see Sect. 2.9).

\subsection{Calculation of the $Q_{10}$ value}

The temperature dependence of the net potential NO flux was determined by using net $\mathrm{NO}$ release rates obtained for two soil temperatures, namely those at $10^{\circ} \mathrm{C}$ and $20^{\circ} \mathrm{C}$. The temperature dependence usually shows an exponential increase and can be expressed by the ratio of two net potential NO fluxes, at soil temperatures $10^{\circ} \mathrm{C}$ apart. The $Q_{10}$ values used for this study were calculated from the net potential NO fluxes at optimum gravimetric soil moisture $\left(\theta_{\mathrm{opt}}\right)$ :

$Q_{10}\left(\theta_{\mathrm{opt}}\right)=\frac{F_{\mathrm{NO}}\left(\theta_{\mathrm{opt}}, T_{\mathrm{soil}}=20^{\circ} \mathrm{C}\right)}{F_{\mathrm{NO}}\left(\theta_{\mathrm{opt}}, T_{\mathrm{soil}}=10^{\circ} \mathrm{C}\right)}$
Table 1. Mathematical formulations for the calculation of the effective diffusion coefficient in soil. $\epsilon$ is the soil air-filled porosity in $\mathrm{m}^{3}$ (soil air) $\mathrm{m}^{-3}$ (soil), $\Phi$ is the soil total porosity in $\mathrm{m}^{3}$ (pores) $\mathrm{m}^{-3}$ (soil) and $D_{0}$ is the gas diffusion coefficient in free air $\left(1.99 \times 10^{-5} \mathrm{~m}^{2} \mathrm{~s}^{-1}\right)$.

\begin{tabular}{lll}
\hline Moldrup (2000) & Millington (1959) & Millington \& Quirk (1961) \\
\hline$D_{p}=\frac{\epsilon^{2.5}}{\Phi}$ & $D_{p}=\epsilon^{3 / 2} \cdot D_{0}$ & $D_{p}=\frac{\epsilon^{10 / 3}}{\Phi^{2}} \cdot D_{0}$ \\
\hline
\end{tabular}

\subsection{Effective diffusion of NO in soil air}

The effective gas diffusion coefficient of NO in soil air is an important parameter for deriving the net potential NO flux from NO production and NO consumption rates (Bollmann and Conrad, 1998). Since we do not have measurements of the effective soil diffusion coefficient $\left(D_{p}\right)$ at the Weidenbrunnen site, we estimated the diffusion coefficient through available functional relationships. The choice of the proper diffusivity coefficient function is not trivial, particularly for organic soils (Kapiluto et al., 2007). Therefore, we tested different functions namely those of Moldrup et al. (2000), Millington (1959) and Millington and Quirk (1960) which are given in Table 1. In these functions the following measured variables were used:

- soil total porosity $(\Phi)$, calculated from the soil bulk density (BD) and the particle density (PD) of the soil sample; both parameters measured directly on the soil samples:

$\Phi=1-\frac{B D}{P D}$

- soil air filled porosity $(\epsilon)$ calculated from the soil bulk density, the density of water $(W D)$, and the the soil total porosity $(\Phi)$ :

$\epsilon=1-\theta \frac{B D}{W D} \cdot \frac{1}{\Phi}$

We calculated net potential NO fluxes (see Sect. 2.7) using the three different effective NO diffusion coefficients. One example for a soil sample from a grass covered patch is shown in Fig. 3. Net potential fluxes exhibit different maxima with a shifting value for the optimum water content for NO production due to the different exponents for $\epsilon$. According to Moldrup (personal communication, 2009), the Millington and Quirk approach describes the effective gas diffusion coefficient best for soil organic matter; therefore the potential NO fluxes of this paper have been calculated using the formulation by Millington and Quirk (1960). 


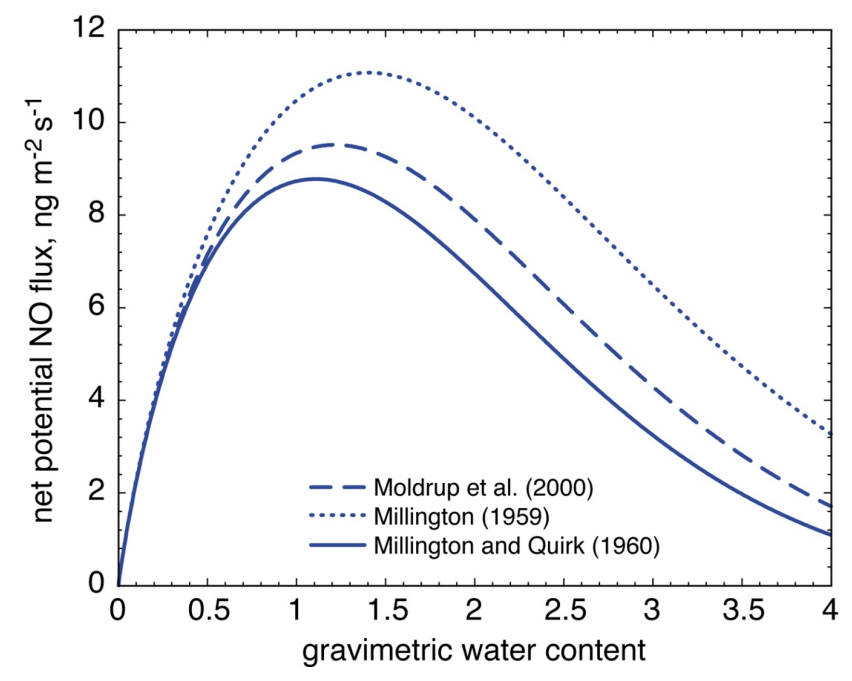

Fig. 3. Net potential NO flux at $10^{\circ} \mathrm{C}$ from a grass covered patch (all expressed in terms of mass of nitrogen). The net potential NO fluxes were calculated according to Eq. (8) applying effective soil diffusion coefficients by Moldrup et al. (2000), Millington (1959) and Millington and Quirk (1960) (see Table 1).

\subsection{Error estimation of NO release measurements}

The errors in the net NO release rate were determined using the individual errors of all quantities on the right hand site of Eq. (1). We specified these errors as followed:

- The error in the soil weight $\left(M_{\text {soil }}\right)$ measurements was set to the accuracy of the balance (PG-S Delta Range ${ }^{\circledR}$, Mettler-Toledo, Switzerland) provided by the manufacturer: $0.001 \mathrm{~kg}$ (for a mass $<1.0 \mathrm{~kg}$ ).

- The error of the mass flow rate through the cuvette (Q) was found as $1.68 \times 10^{-8} \mathrm{~m}^{3} \mathrm{~s}^{-1}$ (i.e. the standard deviation of all individual mean flux rates of a corresponding experiment with $\mathrm{n}=798$ ).

- The error of the mixing ratio in the headspace of a soil cuvette $\left(m_{\mathrm{NO}, \text { out }}\right)$ was determined by using every NO mixing ratio measurement: for $m_{\mathrm{NO} \text {, ref }}=0 \mathrm{ppb}$ the error was $<0.1 \mathrm{ppb}$, for $m_{\mathrm{NO} \text {,ref }}=133 \mathrm{ppb}$ the error was $<0.6 \mathrm{ppb}$.

- The error of the reference cuvette $\left(m_{\mathrm{NO}}\right.$,ref $)$ was determined in the same way, resulting in an error of $<0.1 \mathrm{ppb}$ $\left(m_{\mathrm{NO}, \text { ref }}=0 \mathrm{ppb}\right)$, and $<0.4 \mathrm{ppb}\left(m_{\mathrm{NO}, \text { ref }}=133 \mathrm{ppb}\right)$.

Application of Gaussian error propagation to Eq. (1) resulted in an error in the optimum net NO release rate $\left(\mathrm{J}_{\mathrm{opt}}\right)$ of less than $8 \%$.

The detection limit for the net NO release rate obtained by our laboratory system was determined by Feig et al. (2008) and Gelfand et al. (2009) using inert glass beads and autoclaved soils. The "blank" net NO release
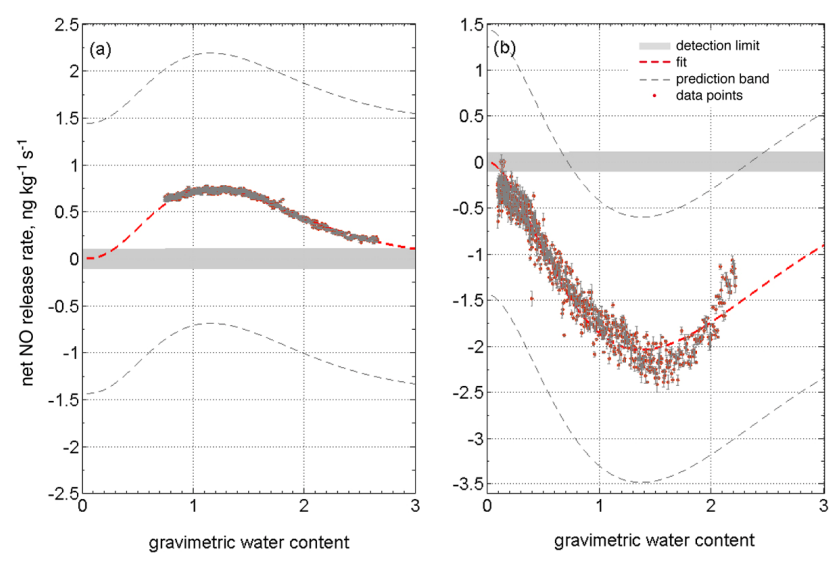

Fig. 4. (a) measured net NO release rates (red dots) at $m_{\mathrm{NO}, \text { ref }}=0 \mathrm{ppb}$ and fitted net NO release rates (red dashed line), for a soil samples covered with moss. (b) measured net NO release rates (red dots) at $m_{\mathrm{NO}, \mathrm{ref}}=133 \mathrm{ppb}$ and fitted net $\mathrm{NO}$ release rates (red dashed line), for a moss covered soil. The grey shaded band indicates the detection of the net NO release rate obtained through our laboratory system. Error bars (grey whiskers) on each individual data point have been calculated by the Gaussian error propagation (see Sect. 2.10). NO release rates in both panels have been obtained for $T_{\text {soil }}=20^{\circ} \mathrm{C}$.

rate from the inert glass beads was $0.02 \mathrm{ng} \mathrm{kg}^{-1} \mathrm{~s}^{-1}$ with a random deviation of $0.02 \mathrm{n} \mathrm{kg}^{-1} \mathrm{~s}^{-1}$ and for autoclaved soils it was $0.05 \mathrm{ng} \mathrm{kg}^{-1} \mathrm{~s}^{-1}$ with a random deviation of $0.02 \mathrm{ng} \mathrm{kg}^{-1} \mathrm{~s}^{-1}$. Feig et al. (2008) defined the detection limit of the net NO release rate as $0.08 \mathrm{ng} \mathrm{kg}^{-1} \mathrm{~s}^{-1}$ (i.e. mean net NO release rate of glass beads plus three times its standard deviation). The detection limit of the autoclaved soils was calculated the same way and resulted in a detection limit of $0.11 \mathrm{ng} \mathrm{kg}^{-1} \mathrm{~s}^{-1}$. Therefore, the more conservative estimate from the autoclaved soils was used as the detection limit of net NO release rates determined by our laboratory system.

In Fig. 4a and b, we present the net NO release rate calculated from the difference in the data points of NO mixing ratio (see Eq. 1) and the corresponding fit (see Eq. 2) for a soil samples under moss. Fig. 4 also shows the individual errors of $\mathbf{J}$ (by Gaussian error propagation; grey whiskers) and the detection limit of $\mathrm{J}$ (grey shadow band).

For the fit of the data according to Eq. (2), prediction bands (PB) were calculated at a confidence level of $95 \%$ using the procedure given by Olive (2007) (Eq. 2.6 in the work by Olive). The prediction bands show for a prescribed probability, the values of one or more hypothetical observations that could be drawn from the same population from which the given data was sampled. 


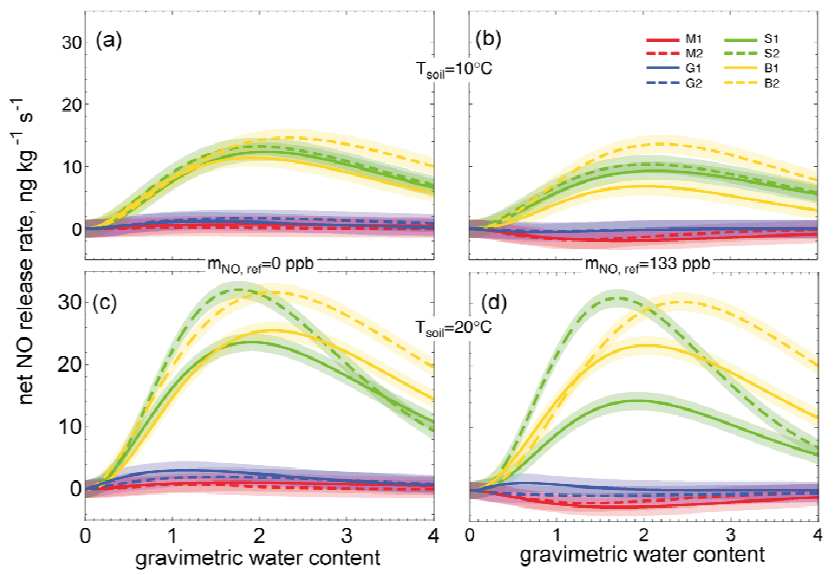

Fig. 5. Net NO release rates fitted through experimental results by Eq. (2) (see Sect. 2.4) at (a) $T_{\text {soil }}=10^{\circ} \mathrm{C}$ and $m_{\mathrm{NO} \text {, ref }}=0 \mathrm{ppb}$, (b) $T_{\text {soil }}=10^{\circ} \mathrm{C}$ and $m_{\mathrm{NO}, \text { ref }}=133 \mathrm{ppb}$, (c) $T_{\text {soil }}=20^{\circ} \mathrm{C}$ and $m_{\mathrm{NO}, \text { ref }}=0 \mathrm{ppb} \mathrm{NO}$ and (d) $T_{\text {soil }}=20^{\circ} \mathrm{C}$ and $m_{\mathrm{NO}, \text { ref }}=133 \mathrm{ppb}$ (all expressed in terms of mass of nitrogen). The transparent bands are the prediction bands of each line (95\% confidence level).

\section{Results}

\subsection{Net NO release rates}

Figures $5 \mathrm{a}-\mathrm{d}$ present net NO release rates obtained from soil samples taken under moss, grass, spruce and blueberry cover at two temperatures (upper panels: $10^{\circ} \mathrm{C}$, and lower panels: $20^{\circ} \mathrm{C}$ ) and two $\mathrm{NO}$ mixing ratios (left panels: $m_{\mathrm{NO}, \text { ref }}=0 \mathrm{ppb}$ and right panels: $\left.m_{\mathrm{NO}, \text { ref }}=133 \mathrm{ppb}\right)$. The curves are the result of corresponding fitting (Eq. 2) to measured data as described in section 2.5. At incubation with $\mathrm{NO}$ free air higher net NO release rates occurred from soil samples taken under spruce $(\mathrm{S} 1, \mathrm{~S} 2)$ and blueberry (B1, B2) cover than under moss (M1, M2) and grass (G1, G2) cover. Maximum NO release rates at $T_{\text {soil }}=10^{\circ} \mathrm{C}$ and $20^{\circ} \mathrm{C}$ were 12.4 and $23.6 \mathrm{ng} \mathrm{kg}^{-1} \mathrm{~s}^{-1}$ for $\mathrm{S} 1,13.2$ and $32.0 \mathrm{ng} \mathrm{kg}^{-1} \mathrm{~s}^{-1}$ for S2, 11.4 and $25.5 \mathrm{ng} \mathrm{kg}^{-1} \mathrm{~s}^{-1}$ for B1, and 14.6 and $33.6 \mathrm{ng} \mathrm{kg}^{-1} \mathrm{~s}^{-1}$ for B2. Similarly, when incubated with $133 \mathrm{ppb}$ NO, soil samples taken under spruce (S1: 9.3 and $14.4 \mathrm{ng} \mathrm{kg}^{-1} \mathrm{~s}^{-1}, \mathrm{~S} 2: 10.4$ and $30.8 \mathrm{ng} \mathrm{kg}^{-1} \mathrm{~s}^{-1}$ ) and blueberry (B1: 6.8 and $23.6 \mathrm{ng} \mathrm{kg}^{-1} \mathrm{~s}^{-1}, \mathrm{~B} 2$ : 13.6 and $30.2 \mathrm{ng} \mathrm{kg}^{-1} \mathrm{~s}^{-1}$ ) cover showed the highest net NO release rates. In contrast, soil samples taken under moss and grass cover showed small net NO release rates when flushed with NO free air (Fig. 5a, c). When flushed with air containing $133 \mathrm{ppb} \mathrm{NO}$, negative net NO release rates occurred for the soil samples S1, S2 and G2. In these cases the flushing NO mixing ratio of $133 \mathrm{ppb}$ was obviously higher than the NO compensation mixing ratio ( $m_{\mathrm{NO} \text {,comp }}$ ) of the corresponding soil samples (see section 2.7), and the NO consumption rate $(\mathrm{K})$ has exceeded the NO production rate $(\mathrm{P})$ in these soil samples.
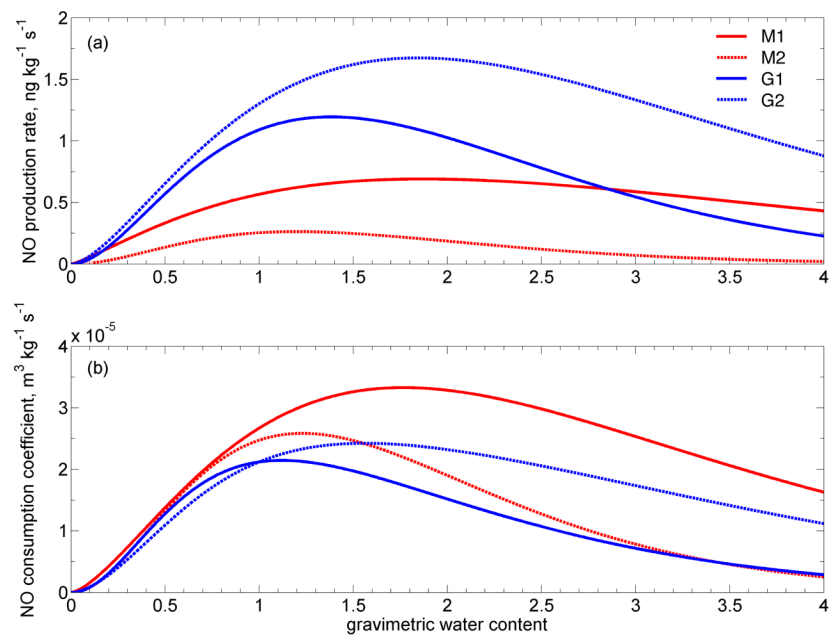

Fig. 6. (a) NO production at $T_{\text {soil }}=10^{\circ} \mathrm{C}$ and (b) NO consumption coefficient at $T_{\text {soil }}=10^{\circ} \mathrm{C}$ from soil samples taken under moss and grass cover (all expressed in terms of mass of nitrogen). The red lines show the production and consumption coefficient of soil samples taken under moss covered patches and the blue lines of soil samples taken under grass covered patches.

Net NO release rates reached their maxima between 0.64 (G1) and 2.41 (B2) gravimetric water content. The soil moisture, where the optimum net NO release rate is observed, is called the optimum soil moisture ( $\theta_{\mathrm{opt}}$ in Eq. 3). Generally, highest values of $\theta_{\text {opt }}$ were observed for S1, S2, B1 and B2.

At gravimetric soil moisture of 4 the net NO release rates do not become zero. That is due to the fact that the samples were not waterlogged at gravimetric soil moisture of 4 . Therefore, nitrifiers and denitrifiers might be still supplied with oxygen.

However, the curves differ for optimum soil moistures and higher than these. The net NO release rates from S1 and S2 were not significantly different from each other using either flushing at $T_{\text {soil }}=10^{\circ} \mathrm{C}$, but significantly differ at $T_{\text {soil }}=20^{\circ} \mathrm{C}$. No significant differences could be observed between the two samples taken under moss cover, or the two samples taken under grass cover. Net NO release rate of soil samples taken under blueberry cover were similar only in a range between 0 and 1.4 gravimetric water content and only in the treatment with NO free air and at $T_{\text {soil }}=10^{\circ} \mathrm{C}$.

\subsection{NO production rates, NO consumption coefficients, and NO compensation point mixing ratios}

Exemplary results of NO production rate and NO consumption coefficient as a function of gravimetric soil water content for $T_{\text {soil }}=10^{\circ} \mathrm{C}$ are shown in Fig. $6 \mathrm{a}$ and $6 \mathrm{~b}$ (for soil samples taken under moss and grass cover). The NO production rate $\mathrm{P}$ (also expressed in $\mathrm{ng} \mathrm{kg}^{-1} \mathrm{~s}^{-1}$ ) is nearly as high as the net NO release rate at $m_{\mathrm{NO} \text {,ref }}=0 \mathrm{ppb}$. The NO production rate exponentially increased with soil moisture 


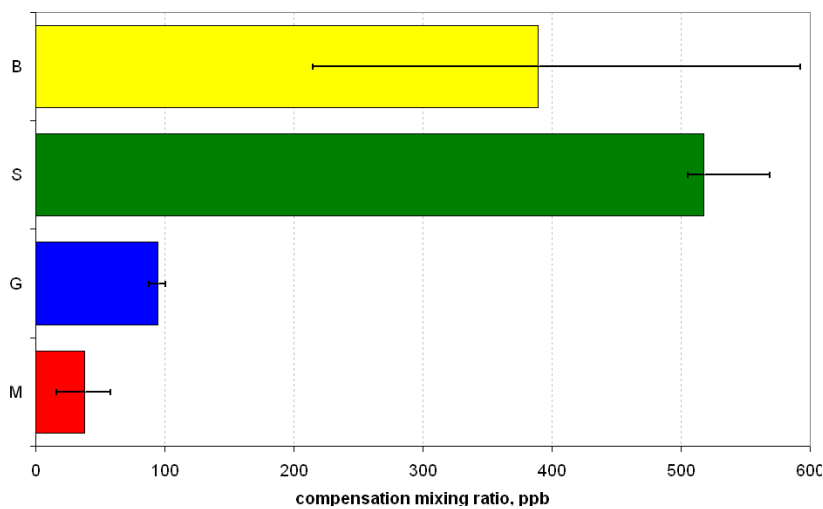

Fig. 7. Median $\mathrm{NO}$ compensation point mixing ratios, $m_{\mathrm{NO}}$, comp (Eq. 7, Sect. 2.7), for all soil probes taken under the different understory types of the Weidenbrunnen site at $1 \pm 0.1$ gravimetric soil moisture and $T_{\text {soil }}=10^{\circ} \mathrm{C}$. The bars indicate the range between the $25 \%$ and $75 \%$ percentile of the data $(n=10$, for each understory type data set).

to a maximum value followed by a moderate decrease at higher soil moistures. This optimum shape of the NO production rate has been explained by substrate limitation under very dry conditions, and $\mathrm{O}_{2}$-diffusion limitation under very wet conditions (Davidson et al., 1993; Meixner, 1994; Rudolph and Conrad, 1996; Meixner and Yang, 2006; Skopp et al., 1990). The lowest optimum NO production rates were found at $T_{\text {soil }}=10^{\circ} \mathrm{C}$ for M1 and M2 with 0.7 and $0.3 \mathrm{ng} \mathrm{kg}^{-1} \mathrm{~s}^{-1}$. G1 and $\mathrm{G} 2$ revealed optima of 1.2 and $1.7 \mathrm{ng} \mathrm{kg}^{-1} \mathrm{~s}^{-1}$. S1 and S2 yield optimum NO production rates of 12.0 and $12.8 \mathrm{ng} \mathrm{kg}^{-1} \mathrm{~s}^{-1}$, and B1 and B2 of 10.9 and $14.5 \mathrm{ng} \mathrm{kg}^{-1} \mathrm{~s}^{-1}$ (see Table 2). The NO production rate at $20^{\circ} \mathrm{C}$ showed generally higher values at optimum soil moisture. The optimum NO production rate for M1 and M2 at $T_{\text {soil }}=20^{\circ} \mathrm{C}$ were 1.1 and $0.7 \mathrm{ng} \mathrm{kg}^{-1} \mathrm{~s}^{-1}$, for G1 and G2 3.0 and $2.0 \mathrm{ng} \mathrm{kg}^{-1} \mathrm{~s}^{-1}, 21.4$ and $31.6 \mathrm{ng} \mathrm{kg}^{-1} \mathrm{~s}^{-1}$ for $\mathrm{S} 1$ and S2, and for B1 and B2 24.8 and $31.2 \mathrm{ng} \mathrm{kg}^{-1} \mathrm{~s}^{-1}$ (see Table 2).

The NO consumption coefficient ( $k$, see Eq. 4) is expressed in $\mathrm{m}^{3} \mathrm{~kg}^{-1} \mathrm{~s}^{-1}$. For our samples, we measured maximum $\mathrm{NO}$ consumption coefficients for $\mathrm{M} 1$ and $\mathrm{M} 2$ of $3 \times 10^{-5} \mathrm{~m}^{3} \mathrm{~kg}^{-1} \mathrm{~s}^{-1}$, for G1 and G2 $2 \times 10^{-5} \mathrm{~m}^{3} \mathrm{~kg}^{-1} \mathrm{~s}^{-1}$ for both, $4 \times 10^{-5} \mathrm{~m}^{3} \mathrm{~kg}^{-1} \mathrm{~s}^{-1}$ for S1 and S2 and $6 \times 10^{-5}$ and $3 \times 10^{-5} \mathrm{~m}^{3} \mathrm{~kg}^{-1} \mathrm{~s}^{-1}$ for $\mathrm{B} 1$ and B2 (all values for $T_{\text {soil }}=10^{\circ} \mathrm{C}$, see Table 3 for NO consumption at $T_{\text {soil }}=20^{\circ} \mathrm{C}$ ).

Fig. 7 presents mean NO compensation point mixing ratios $\left(m_{\mathrm{NO}, \text { comp }}\right)$ for all eight soil samples at gravimetric soil moisture of $1 \pm 0.1$ which is at the upper end of gravimetric soil moistures observed at the sample site (Behrendt, 2009). The $m_{\mathrm{NO} \text {,comp }}$ varies over a wide range. Soil samples taken under moss and grass cover showed small $m_{\mathrm{NO} \text {,comp }}$ ( $38 \mathrm{ppb}$ and 94 $\mathrm{ppb}$ ) compared to soil samples taken under spruce and blueberry cover which exhibited considerable higher $m_{\mathrm{NO}}$,comp (518 ppb and $389 \mathrm{ppb}$ ).

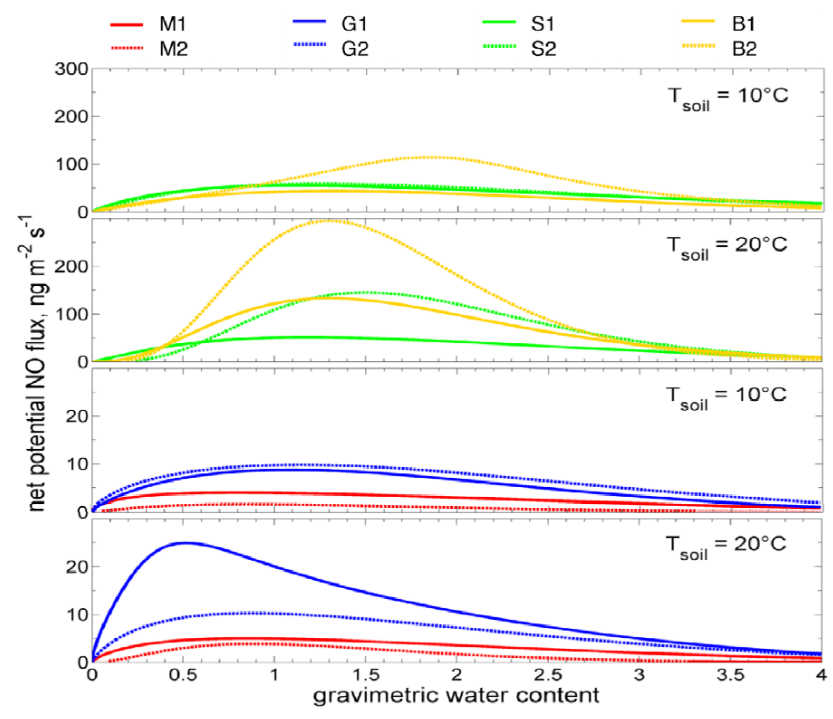

Fig. 8. Net potential NO flux (all expressed in terms of mass of nitrogen) at $10^{\circ} \mathrm{C}$ and $20^{\circ} \mathrm{C}$ from soil samples taken under moss, spruce and blueberry covered patches (note different scales of the y-axes).

\subsection{Net potential NO fluxes}

Net potential NO fluxes derived from measured net NO release rates from soil samples taken under different understory covers are given in Fig. 8. It is remarkable, that the net potential NO fluxes from soil samples taken under spruce and blueberry cover were approximately 10 -fold higher than net potential NO fluxes from soil samples taken under moss and grass cover (note different scales of y-axes in Fig. 8). The optimum NO fluxes at $T_{\text {soil }}=10^{\circ} \mathrm{C}$ ranged between 1.7 $\mathrm{ng} \mathrm{m}^{-2} \mathrm{~s}^{-1}$ (M2) and $114.6 \mathrm{ng} \mathrm{m}^{-2} \mathrm{~s}^{-1}$ (B2). The position of the optimum gravimetric water content varied between the different curves. The optimum gravimetric water content for $T_{\text {soil }}=10^{\circ} \mathrm{C}$ was 0.8 for M1 and M2, 1.1 for G1 and G2, 1.3 for $\mathrm{S} 1$ and $\mathrm{S} 2$ and 1.3 for $\mathrm{B} 1$ and 1.5 for $\mathrm{B} 2$ gravimetric soil moisture (also see Table 2). For flushing at $T_{\text {soil }}=20^{\circ} \mathrm{C}$, optimum net potential NO fluxes were, except for $\mathrm{S} 1$, always higher at the higher incubation temperature. They ranged between $3.9 \mathrm{ng} \mathrm{m}^{-2} \mathrm{~s}^{-1}(\mathrm{M} 2)$ and $295 \mathrm{ng} \mathrm{m}^{-2} \mathrm{~s}^{-1}$ (B2) (see Table 2). Optimum gravimetric water content for $T_{\text {soil }}=20^{\circ} \mathrm{C}$ were 0.8 and 0.9 for M1 and M2, 0.5 and 0.8 for G1 and G2, 1.2 and 1.5 for $\mathrm{S} 1$ and $\mathrm{S} 2$, and 1.3 for $\mathrm{B} 1$ and $\mathrm{B} 2$.

\subsection{Temperature dependence $\left(Q_{10}\right.$ values $)$}

Optimum net potential NO fluxes measured at two different soil temperatures $\left(10^{\circ} \mathrm{C}\right.$ and $\left.20^{\circ} \mathrm{C}\right)$ allowed us to estimate $\mathrm{Q}_{10}$ values for each soil sample of the Weidenbrunnen site and data are given in Table 2. For $\mathrm{S} 1$ we derived the lowest $\mathrm{Q}_{10}$ value (0.92). B1 showed the highest $\mathrm{Q}_{10}$ value of 3.04. 
Table 2. Net potential NO flux (in terms of mass of nitrogen) calculated with the diffusion coefficient according to Millington and Quirk (1960); NO production rates $\left(\mathrm{P}_{\mathrm{opt}}\right)$ and the $\mathrm{NO}$ consumption coefficients $\left(\mathrm{k}_{\mathrm{opt}}\right)$ are calculated for $10^{\circ} \mathrm{C}$ and $20^{\circ} \mathrm{C}$ and the $\mathrm{Q}_{10}$ values. All values are at optimum gravimetric soil moisture $\left(\theta_{\mathrm{opt}}\right)$.

\begin{tabular}{|c|c|c|c|c|c|c|c|c|c|c|}
\hline $\begin{array}{l}\text { soil } \\
\text { samples }\end{array}$ & $\begin{array}{l}\text { understory } \\
\text { vegetation }\end{array}$ & $\begin{array}{l}\text { optimum gravi- } \\
\text { metric water } \\
\text { content }\left(10^{\circ} \mathrm{C}\right) \\
{[1]}\end{array}$ & $\begin{array}{l}\text { optimum net po- } \\
\text { tential NO flux } \\
\left(10^{\circ} \mathrm{C}\right) \\
\left(\mathrm{ng} \mathrm{m}^{-2} \mathbf{s}^{-1}\right)\end{array}$ & $\begin{array}{l}\text { optimum gravi- } \\
\text { metric water } \\
\text { content }\left(20^{\circ} \mathrm{C}\right) \\
{[1]}\end{array}$ & $\begin{array}{l}\text { optimun net po- } \\
\text { tential NO flux } \\
\left(20^{\circ} \mathrm{C}\right) \\
\left(\mathrm{ng} \mathrm{m}^{-2} \mathrm{~s}^{-1}\right)\end{array}$ & $\begin{array}{l}P_{\mathrm{opt}} \\
\left(10^{\circ} \mathrm{C}\right) \\
\left(\mathrm{ng} \mathrm{kg}^{-1} \mathrm{~s}^{-1}\right)\end{array}$ & $\begin{array}{l}k_{\mathrm{Opt}} \\
\left(10^{\circ} \mathrm{C}\right) \\
\left(\mathrm{m}^{3} \mathrm{~kg}^{-1} \mathrm{~s}^{-1}\right)\end{array}$ & $\begin{array}{l}P_{\mathrm{opt}} \\
\left(20^{\circ} \mathrm{C}\right) \\
\left(\mathrm{ng} \mathrm{kg}^{-1} \mathrm{~s}^{-1}\right)\end{array}$ & $\begin{array}{l}k_{\mathrm{opt}} \\
\left(20^{\circ} \mathrm{C}\right) \\
\left(\mathrm{m}^{3} \mathrm{~kg}^{-1} \mathrm{~s}^{-1}\right)\end{array}$ & $\begin{array}{l}Q_{10} \\
{[1]}\end{array}$ \\
\hline M1 & moss & 0.8 & 4.0 & 0.8 & 5.0 & 0.7 & $3.3 \times 10^{-5}$ & 1.1 & $5.1 \times 10^{-5}$ & 1.25 \\
\hline M2 & moss & 0.8 & 1.7 & 0.9 & 3.9 & 0.3 & $2.6 \times 10^{-5}$ & 0.7 & $3.7 \times 10^{-5}$ & 2.29 \\
\hline G1 & grass & 1.1 & 8.8 & 0.5 & 24.9 & 1.2 & $2.1 \times 10^{-5}$ & 3.0 & $3.4 \times 10^{-5}$ & 2.83 \\
\hline $\mathrm{G} 2$ & grass & 1.1 & 9.8 & 0.9 & 10.3 & 1.7 & $2.4 \times 10^{-5}$ & 2.0 & $3.7 \times 10^{-5}$ & 1.05 \\
\hline S1 & spruce & 1.3 & 55.4 & 1.2 & 51.1 & 12.0 & $4 \times 10^{-5}$ & 21.4 & $1.4 \times 10^{-5}$ & 0.92 \\
\hline $\mathrm{S} 2$ & spruce & 1.3 & 59.3 & 1.5 & 145.0 & 12.8 & $3.7 \times 10^{-5}$ & 31.6 & $4.3 \times 10^{-5}$ & 2.45 \\
\hline B1 & blueberry & 1.3 & 43.7 & 1.3 & 133.0 & 10.9 & $6.1 \times 10^{-5}$ & 24.8 & $4.2 \times 10^{-5}$ & 3.04 \\
\hline B2 & blueberry & 1.5 & 114.6 & 1.3 & 295.0 & 14.5 & $2.8 \times 10^{-5}$ & 31.2 & $2.6 \times 10^{-5}$ & 2.6 \\
\hline
\end{tabular}

\subsection{Chemical and physical soil parameters}

The results of analysis of different soil parameters including bulk density (BD), particle density (PD), soil pH, C/N ratio, organic carbon $\left(\mathrm{c}_{\mathrm{org}}\right)$, soil ammonia $\left(\mathrm{NH}_{4}^{+}\right)$and soil nitrate $\left(\mathrm{NO}_{3}^{-}\right)$are summarized in Table 3 . Soil bulk density ranged between 0.12 and $0.18 \times 10^{3} \mathrm{~kg} \mathrm{~m}^{-3}$, while PD ranged between 1.5 and $1.7 \times 10^{3} \mathrm{~kg} \mathrm{~m}^{-3}$. Soil $\mathrm{pH}$ was lowest (3.5) in soil samples taken under spruce cover (S1, S2) and highest (5.0) for soil samples taken under moss cover (M1, M2). C/N ratios for all soil samples taken from the organic layers are relatively low, but on average (16.2) close to the range reported in literature for other Norway spruce sites in the Fichtelgebirge (see Schmitt et al., 2008; Michel et al., 2006). $\mathrm{C} / \mathrm{N}$ ratios varied only in a small range, namely between 14.7 and 18.4. For $\mathrm{C}_{\text {org }}$ the values ranged between $26.9 \%(\mathrm{M} 2)$ and $43.5 \%$ (S1). A higher variability has been found for soil $\mathrm{NH}_{4}^{+}$. Lowest soil $\mathrm{NH}_{4}^{+}$values were found for $\mathrm{S} 1\left(56 \mathrm{mg} \mathrm{kg}^{-1}\right)$ and $\mathrm{S} 2\left(86 \mathrm{mg} \mathrm{kg}^{-1}\right)$ and the highest soil $\mathrm{NH}_{4}^{+}$values were found for G1 $\left(207 \mathrm{mg} \mathrm{kg}^{-1}\right)$ and G2 (204 $\mathrm{mg} \mathrm{kg}^{-1}$ ) (expressed in mass of $\mathrm{N}$ ). Soil $\mathrm{NO}_{3}^{-}$ranged between 1 and $11 \mathrm{mg} \mathrm{kg}^{-1}$ (expressed in mass of $\mathrm{N}$ ).

Pearson's product-moment-analyses were performed to test (a) net potential NO fluxes (at $T_{\text {soil }}=10^{\circ} \mathrm{C}, T_{\text {soil }}=20^{\circ} \mathrm{C}$ ), (b) NO production rates (at $T_{\text {soil }}=10^{\circ} \mathrm{C}, T_{\text {soil }}=20^{\circ} \mathrm{C}$ ) and (c) NO consumption coefficients (at $T_{\text {soil }}=10^{\circ} \mathrm{C}, T_{\text {soil }}=20^{\circ} \mathrm{C}$ ) for possible relationship with the physical and chemical soil parameters (soil $\mathrm{pH}, \mathrm{C}_{\mathrm{org}}, \mathrm{C} / \mathrm{N}$ ratio, soil $\mathrm{NH}_{4}^{+}$, soil $\mathrm{NO}_{3}^{-}$and PD).

The results obtained from Pearson's product-momentanalyses are presented in Table 4. Significant negative correlations (probability level of 0.1 ) were found only between soil $\mathrm{NH}_{4}^{+}$and $\mathrm{NO}$ production rate at $T_{\text {soil }}=10^{\circ} \mathrm{C}$, NO production rate at $T_{\text {soil }}=20^{\circ} \mathrm{C}$, and $\mathrm{NO}$ consumption coefficient at $T_{\text {soil }}=20^{\circ} \mathrm{C}$. The following correlations were not significant at a probability level of 0.1 . Soil $\mathrm{pH}$ correlated negatively with all independent variables except for the consumption coefficient at $T_{\text {soil }}=10^{\circ} \mathrm{C}$. Positive correlations with the individual variables were found for soil $\mathrm{C}_{\text {org }}$ and also for $\mathrm{C} / \mathrm{N}$. Soil $\mathrm{NO}_{3}^{-}$vs. independent variables showed positive correlations except for the NO consumption coefficient. Particle density correlated negatively with independent variables, except for the NO consumption coefficient.

\section{Discussion}

\subsection{Comparison with other studies}

During the last two decades, there has been a series of studies on biogenic NO emissions from soil in forest ecosystems (Papke and Papen, 1998; Pilegaard et al., 1999, 2006; Kesik et al., 2005; Johansson, 1984; Butterbach-Bahl et al., 2001, 2002; Lehmann, 2002). However, there are only a few studies examining spatial differences of NO fluxes within a forest (Gasche and Papen, 1999; Lehmann, 2002; Pilegaard et al., 1999; Nishina et al., 2009). Furthermore, the influence of soil organic matter on soil biogenic NO emissions has not been studied in detail and is consequently not well known. In most studies the effect of the dominant overstory or of the whole soil core (mineral and organic layer) was addressed by measurements using the dynamic chamber technique (Gasche and Papen, 1999; Butterbach-Bahl et al., 1997; Johansson, 1984).

During the last two decades, a series of field and laboratory studies clearly demonstrated, that NO fluxes, measured in the field by dynamic chamber techniques, were in good agreement with those NO fluxes, which have been derived from laboratory incubations on soils sampled from the top soil layer of dynamic chambers' enclosures (Meixner et al., 1997; van Dijk et al., 2002; Remde et al., 1993; Ludwig et al., 2001; Meixner and Yang, 2006; Otter et al., 1999). However, for more detailed investigations, laboratory studies are necessary, but only a few groups seem to have the facilities available to carry out laboratory measurements of 
Table 3. Chemical and physical soil parameters from organic soil layers under different understories from Weidenbrunnen research site. $\mathrm{NH}_{4}^{+}$and $\mathrm{NO}_{3}^{-}$are expressed in terms of mass of $\mathrm{N}$.

\begin{tabular}{|c|c|c|c|c|c|c|c|c|}
\hline soil samples & $\begin{array}{l}\text { understory } \\
\text { vegetation }\end{array}$ & $\begin{array}{l}\text { bulk density } \\
\left(10^{3} \mathrm{~kg} \mathrm{~m}^{-3}\right)\end{array}$ & $\begin{array}{l}\text { particle density } \\
\left(10^{3} \mathrm{~kg} \mathrm{~m}^{-3}\right)\end{array}$ & $\begin{array}{l}\mathrm{pH} \\
\text { (measured in } \\
\mathrm{H}_{2} \mathrm{O} \text { ) } \\
{[1]}\end{array}$ & $\begin{array}{l}\mathrm{C} / \mathrm{N} \\
{[1]}\end{array}$ & $\begin{array}{l}\mathrm{C}_{\text {org }} \\
{[\%]}\end{array}$ & $\begin{array}{l}\mathrm{NH}_{4}^{+} \\
\mathrm{mg} \mathrm{kg}^{-1} \\
\text { (dry soil) }\end{array}$ & $\begin{array}{l}\mathrm{NO}_{3}^{-} \\
\mathrm{mg} \mathrm{kg}^{-1} \\
\text { (dry soil) }\end{array}$ \\
\hline M1 & moss & 0.15 & 1.5 & 4.6 & 16.4 & 43.3 & 194 & 2 \\
\hline M2 & moss & 0.12 & 1.7 & 5 & 16.6 & 26.9 & 148 & 7 \\
\hline G1 & grass & 0.15 & 1.7 & 4.1 & 14.7 & 29.5 & 207 & 1 \\
\hline $\mathrm{G} 2$ & grass & 0.13 & 1.5 & 3.6 & 15.4 & 40.0 & 204 & 2 \\
\hline $\mathrm{S} 1$ & spruce & 0.14 & 1.6 & 3.5 & 16.9 & 43.5 & 56 & 2 \\
\hline S2 & spruce & 0.14 & 1.6 & 3.5 & 18.4 & 30.2 & 86 & 11 \\
\hline B1 & blueberry & 0.18 & 1.6 & 4.7 & 15.3 & 36.5 & 139 & 1 \\
\hline B2 & blueberry & 0.15 & 1.5 & 3.7 & 15.6 & 39.0 & 148 & 2 \\
\hline
\end{tabular}

Table 4. Results of Pearson product moment correlation analysis of net NO release rates, net potential NO flux, NO production rate $(P)$ and NO consumption coefficient $(k)$ versus physical and chemical soil parameters.

\begin{tabular}{lllllll}
\hline & NO flux & $\mathrm{P}$ & $\mathrm{k}$ & $\mathrm{NO}$ flux & $\mathrm{P}$ & $\mathrm{k}$ \\
& $10^{\circ} \mathrm{C}$ & $10^{\circ} \mathrm{C}$ & $10^{\circ} \mathrm{C}$ & $20^{\circ} \mathrm{C}$ & $20^{\circ} \mathrm{C}$ & $20^{\circ} \mathrm{C}$ \\
\hline $\mathrm{pH}$ & -0.537 & -0.523 & 0.206 & -0.356 & -0.468 & -0.311 \\
$\mathrm{C}$ org & 0.226 & 0.213 & 0.227 & 0.066 & 0.095 & 0.495 \\
$\mathrm{C} / \mathrm{N}$ & 0.157 & 0.332 & 0.137 & 0.043 & 0.364 & 0.325 \\
$\mathrm{NH}_{4}^{+}$ & -0.519 & $-0.739^{\mathrm{a}}$ & -0.467 & -0.315 & $-0.698^{\mathrm{a}}$ & $-0.662^{\mathrm{a}}$ \\
$\mathrm{NO}_{3}^{-}$ & 0.061 & 0.172 & -0.033 & 0.091 & 0.274 & -0.083 \\
$\mathrm{PD}$ & -0.367 & -0.181 & 0.023 & -0.387 & -0.149 & 0.171 \\
\hline
\end{tabular}

a Significant at the 0.10 probability level.

soil NO exchange (e.g. Bollmann et al., 1999; Ormeci et al., 1999; Schindlbacher et al., 2004; Feig et al., 2008; van Dijk and Meixner, 2001). Since laboratory studies are outnumbered, most of the following discussion is based on results from field measurements in spruce forests.

Pilegaard et al. (1999), applying a dynamic field chamber technique in a spruce forest site at Ulborg (Denmark), found low NO fluxes from moss covered soil. However, NO fluxes increased with closeness to standing tree trunks. For their forest soils which had a thick organic layer $(4 \mathrm{~cm})$, NO fluxes ranged between $<0.3$ and $66 \mathrm{ng} \mathrm{m}^{-2} \mathrm{~s}^{-1}$. Similar results were presented by Gasche and Papen (2002) for the Höglwald forest (Germany). Their measurements, also employing a dynamic chamber technique, addressed the spatial distribution of NO fluxes along a tree-to-tree gradient. For 1997, annual mean NO fluxes of $29.2 \pm 0.9 \mathrm{ng} \mathrm{m}^{-2} \mathrm{~s}^{-1}$ were found for those chambers which were located closest to the stems, $18.4 \pm 0.5 \mathrm{ng} \mathrm{m}^{-2} \mathrm{~s}^{-1}$ for chambers approx. $4 \mathrm{~m}$, and $12.3 \pm 0.4 \mathrm{ng} \mathrm{m}^{-2} \mathrm{~s}^{-1}$ for the chamber approx. $6 \mathrm{~m}$ apart from the stems. With closeness to trunks (living trees) the NO emissions increased significantly (between 1.6- and 2.6-fold). While for the Höglwald beech for- est site, Gasche and Papen (2002) could explain an identical spatial effect with marked differences in soil physical and chemical soil parameters, there was no detailed explanation for the Höglwald spruce forest site. One reason could be that the nutrient supply from stem flow is negligible at this spruce forest site (Gasche and Papen, 2002). ButterbachBahl et al. (1997) reported mean monthly NO fluxes between 5.6 and $36.1 \mathrm{ng} \mathrm{m}^{-2} \mathrm{~s}^{-1}$ for the same Höglwald spruce forest site (July 1994 to June 1995). The site exhibits acidic soil $\mathrm{pH}$ values (2.7 to 3.6) in the organic layer. Again for the Höglwald spruce site, Gasche and Papen (1999) showed, that most of the NO emissions came from the organic layer and only a small contribution from the mineral soil. For the entire Höglwald site, they reported annual NO emission rates of $25.5 \pm 0.5 \mathrm{ng} \mathrm{m}^{-2} \mathrm{~s}^{-1}$ during 1994-1996. Very low NO fluxes $\left(0.3 \pm 0.1 \mathrm{ng} \mathrm{m}^{-2} \mathrm{~s}^{-1}\right)$ were reported by Horváth et al. (2006) for a spruce forest site in NE Hungary (October 2002 to September 2003). Similar low NO fluxes were reported by Kitzler et al. (2006) for the spruce-fir-beech forest site of Achental (Austria) during the period of May 2002 to July 2004. Using a dynamic chamber technique, they found mean NO fluxes of only $0.2 \pm 0.02 \mathrm{ng} \mathrm{m}^{-2} \mathrm{~s}^{-1}$ for the 
first year and mean NO fluxes of $0.14 \pm 0.01 \mathrm{ng} \mathrm{m}^{-2} \mathrm{~s}^{-1}$ for the second year. However, the $\mathrm{pH}$ values at this site are very high (6.42).

Laboratory studies on undisturbed soil samples from the Weidenbrunnen site (approx. $300 \mathrm{~m}$ west of our site) resulted in NO fluxes between 2.6 and $12.9 \mathrm{ng} \mathrm{m}^{-2} \mathrm{~s}^{-1}$ (Muhr et al., 2008). This site is also a spruce site mainly covered with grass. Another laboratory study on mineral soil samples (taken just from the A horizon) were carried out at the Nagoya University Forest (Japan) site covered with Japanese cedar. The NO emissions ranged from $0.3 \mathrm{ng} \mathrm{m}^{-2} \mathrm{~s}^{-1}$ at high soil water contents ( $<92 \%$ WFPS) to $72.2 \mathrm{ng} \mathrm{m}^{-2} \mathrm{~s}^{-1}$ at low soil water contents ( $>29 \%$ WFPS)()(Nishina et al., 2009).

Our optimum net potential NO fluxes for soil samples taken under grass cover $\left(8.8-9.8 \mathrm{ng} \mathrm{m}^{-2} \mathrm{~s}^{-1}, T_{\text {soil }}=10^{\circ} \mathrm{C}\right.$, see Table 2) agree well with the (laboratory) results of Muhr et al. (2008). Also the results of Nishina et al. ()(2009) are in the range of our optimum net potential NO fluxes. However, their soil samples were taken from the mineral soil. Our results for soil samples taken under grass cover also overlap with the data given by Butterbach-Bahl et al. (1997) and Gasche and Papen (2002). Annual NO emission rates measured by Gasche and Papen (1999) range between our optimum net potential NO fluxes for soil samples taken under grass and spruce cover (and also for the B1 sample). Contrastingly, the NO fluxes found by Kitzler et al. (2006) and Horváth et al. (2006) are much lower than any of our optimum net potential NO fluxes. However, the Achental site is a mixed forest, and the soil exhibits a relatively high $\mathrm{pH}$ value (6.42). Relatively high values of the soil water content (average: 53\% WFPS) characterized the soils of the Hungarian site (see Horváth et al., 2006). In contrast, the optimum soil water contents found in our study ranged between 18 and $27 \%$ WFPS (see equivalent gravimetric water contents in Table 2). Optimum net potential NO fluxes of our moss covered soils (if watered to 53\% WFPS) would fall in the range of field fluxes observed by Horváth et al. (2006). In any case, our optimum net potential NO fluxes from soils under spruce and blueberries show higher values than any fluxes of the other studies mentioned above.

Net potential NO fluxes derived from laboratory experiments using the algorithm of Galbally and Johansson (1989) are particularly sensitive to changes in NO production rates and NO consumption coefficients and less sensitive to changes in diffusivity and soil bulk density (Rudolph and Conrad, 1996). In this respect, when comparing NO soil flux estimates (derived from laboratory incubation measurements), with data from literature, one should keep in mind, that the most up-to-date diffusion coefficient equations are basically applicable only to mineral soils. As gas diffusion in the organic layer can be substantially different, and uncertainties in determining diffusion coefficients in organic layers are still a matter of discussion (Moldrup, personal communication), we employed different mathematical formulations (see Table 1), and found that the choice of the diffusion coef- ficient equation had an effect on the calculated NO flux (see Fig. 3). Depending on the diffusion coefficient, the NO fluxes had different magnitudes (factor of maximum 1.26 over the entire soil moisture range) and exhibited a shift in the position of the optimum flux (see Fig. 3). However, even using the correct effective diffusion coefficient, attention should be paid to its determination as the equation includes both the bulk and particle density. Both densities vary significantly between organic and mineral soil layers (e.g. Weidenbrunnen site: organic soil layers: BD: $0.14 \pm 0.02$, PD: $1.6 \pm 0.07$, $n=8$, mineral soil layers: BD: $0.88 \pm 0.18$, PD: $2.47 \pm 0.06$, $n=8$ ). If the effective diffusion coefficient has to be calculated, it is necessary to measure these quantities directly. Nevertheless, to reveal the uncertainties in diffusion through organic soil layers, further research, especially through field measurements of the diffusion coefficient, are most desirable.

Comparisons of NO production rates are not affected by the choice of diffusion coefficients. Therefore, only a few NO production rates are reported in the literature. Venterea and Rolston (2000) found mean NO production rates in a range of 9.4 to $18.7 \mathrm{ng} \mathrm{kg}^{-1} \mathrm{~s}^{-1}$ for agricultural soils from the Sacramento Valley of California. These values are comparable with our results of NO production rates (0.3$14.5 \mathrm{ng} \mathrm{kg}^{-1} \mathrm{~s}^{-1}$ ). Remde et al. (1989) reported NO production rates twice as high as ours for a sandy clay loam under aerobic conditions $\left(27.4 \pm 1.8 \mathrm{ng} \mathrm{kg}^{-1} \mathrm{~s}^{-1}\right)$, yet much higher under anaerobic conditions $\left(738 \pm 21.6 \mathrm{ng} \mathrm{kg}^{-1} \mathrm{~s}^{-1}\right)$.

$\mathrm{NO}$ production rates reported in the literature are as rare as NO consumption coefficients. Values of the NO consumption coefficient $(\mathrm{k})$ found in this study were in the range of $2 \times 10^{-5}$ to $6 \times 10^{-5} \mathrm{~m}^{3} \mathrm{~s}^{-1} \mathrm{~kg}^{-1}$. Soils from the Bolivian Amazon region showed $\mathrm{k}$ values under oxic conditions of $8 \times 10^{-5} \mathrm{~m}^{3} \mathrm{~s}^{-1} \mathrm{~kg}^{-1}$ (Koschorreck and Conrad, 1997). Feig et al. (2008) reported NO consumption coefficients between $5 \times 10^{-5}$ and $26 \times 10^{-5} \mathrm{~m}^{3} \mathrm{~s}^{-1} \mathrm{~kg}^{-1}$. However, these values were determined for desert soil with nearly no organic material inside at $25^{\circ} \mathrm{C}$ in the laboratory, $15^{\circ} \mathrm{C}$ more than for our studies. As biological processes usually increase by a factor of two with an increase in temperature of $10^{\circ} \mathrm{C}$ (Kirschbaum, 1995; Davidson et al., 2006; Zheng et al., 2003), the higher values reported by Feig et al. (2008) are to be expected.

Only a few studies reported compensation point mixing ratios. Slemr and Seiler (1991) determined NO compensation point mixing ratio for agricultural soils between 0.3 and $5.5 \mathrm{ppb}$. Gasche and Papen (1999) found NO compensation point mixing ratios of $69.9 \pm 9.6 \mathrm{ppb}$ for a spruce forest soil in the Höglwald, Germany. Only for G1 and G2 we found NO compensation points in the low range of these studies. Soil samples taken under spruce and blueberry cover showed

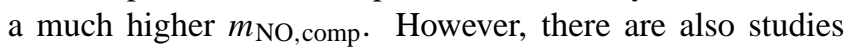
which found higher NO compensation mixing ratios, e.g. ranging between 9 and $875 \mathrm{ppb}$ for agriculture, meadow and forest soils (Gödde and Conrad, 2000). In view of the ambient NO mixing ratios observed at the Weidenbrunnen site, NO compensation point mixing ratios found in our study 
demonstrate, that the soils there mainly act as a biogenic source for NO. Only when the ambient NO mixing ratio matches or falls below the NO compensation point mixing ratio will the soils become a sink for biogenic NO. Moravek (2008) observed ambient NO mixing ratios between 1 and $2 \mathrm{ppb}$ at $5 \mathrm{~cm}$ above the forest floor (moss covered) and Plake (2009) found NO mixing ratios up to $4.2 \mathrm{ppb}$ at $0.5 \mathrm{~cm}$ above the forest floor (moss covered), both at the Weidenbrunnen site. These mixing ratios are too low to change the NO flux from upward to downward directions.

Many studies have presented an exponential increase of soil NO emissions with increasing temperature. Generally, $\mathrm{Q}_{10}$ values are in the range of 2-3, a range valid for most biochemical processes (Koponen et al., 2006; Kirkman et al., 2002; van Dijk et al., 2002; Feig et al., 2008; Meixner and Yang, 2006; Smith et al., 2003). We obtained $\mathrm{Q}_{10}$ values for net potential NO fluxes between 0.92 and 3.04 (see Table 3). However, a $\mathrm{Q}_{10}$ value less than 1 (e.g. S1: 0.92) indicates a decrease of soil $\mathrm{NO}$ emission with increasing temperature.

\subsection{Influence of soil chemical parameters on net potential NO flux}

The processes which result in NO exchange are mainly influenced by soil temperature and soil moisture (Davidson and Kingerlee, 1997; Johansson and Granat, 1984; Skiba et al., 1997; Ludwig et al., 2001; Feig et al., 2008; Meixner, 1994; Meixner and Yang, 2006). Nevertheless, soil chemical and physical parameters may also affect the NO exchange (Nägele and Conrad, 1990a; Smith et al., 2003; Ludwig et al., 2001; Pilegaard et al., 2006; Kitzler et al., 2006; Laville et al., 2009; Gödde and Conrad, 2000).

For our soil samples from the Weidenbrunnen site we found no significant (probability level of 0.05 ) relationships between optimum net potential NO fluxes, NO production rates, or NO consumption coefficients with any physical or chemical soil parameters. However, on the 0.1 significance level we found negative correlations between soil $\mathrm{NH}_{4}^{+}$and (a) NO production rate (at $T_{\text {soil }}=10^{\circ} \mathrm{C}$ ), (b) $\mathrm{NO}$ production rate (at $T_{\text {soil }}=20^{\circ} \mathrm{C}$ ), and (c) NO consumption coefficient (at $T_{\text {soil }}=20^{\circ} \mathrm{C}$ ) (see Table 4$)$. Also the NO consumption coefficient at $T_{\text {soil }}=10^{\circ} \mathrm{C}$ and the net potential NO fluxes showed a negative, but not significant correlation with soil $\mathrm{NH}_{4}^{+}$. These negative correlations with soil $\mathrm{NH}_{4}^{+}$point to nitrification as the main converting process, because soil $\mathrm{NH}_{4}^{+}$must be available before nitrification may start. Denitrification is the conversion of $\mathrm{NO}_{3}^{-}$to $\mathrm{N}_{2} \mathrm{O}$ or $\mathrm{N}_{2}$, and $\mathrm{NO}_{3}^{-}$is necessary for the activation of denitrification. However, denitrification seems to play a smaller role for soils from the Weidenbrunnen site because we found no significant correlation between soil $\mathrm{NO}_{3}^{-}$and other variables (see Table 4). Furthermore, nitrification may be lower from soil samples taken under moss and grass than from soil samples taken under spruce and blueberry cover. Therefore, the amount of soil $\mathrm{NH}_{4}^{+}$is higher at soil samples taken under moss and grass than at soil samples taken under spruce and blueberry cover. Gödde and Conrad (2000) also found, that nitrification is the dominant process of NO production in the soil. In contrast to our study, Baumgärtner and Conrad (1992) found no significant correlation between the $\mathrm{NO}$ production rate and soil $\mathrm{NH}_{4}^{+}$, but did find a significant correlation between the $\mathrm{NO}$ consumption coefficient and soil $\mathrm{NH}_{4}^{+}$. However, they investigated mineral soil only. NO production and $\mathrm{NO}$ consumption processes are differently regulated (Dunfield and Knowles, 1998), so that both processes can respond independantly to changes in external factors. Gasche and Papen (1999) found a correlation between $\mathrm{NO}$ fluxes and soil $\mathrm{NH}_{4}^{+}$ for the Höglwald spruce forest site as well as a correlation between $\mathrm{NO}$ fluxes and soil $\mathrm{NO}_{3}^{-}$. Typically, $1-4 \%$ (sometimes more) of soil $\mathrm{NH}_{4}^{+}$is released from soil as $\mathrm{NO}$ (Dunfield and Knowles, 1998).

The other parameters showed no significant correlations $(<0.1)$. As the research site, a typical even-aged monoculture, is relatively small (1.4 ha), soil parameters vary only over a small range (see also Behrendt, 2009). This makes it difficult or impossible to establish significant correlations between the other soil chemical or physical parameters and net potential NO fluxes.

Nevertheless, net potential NO fluxes showed a weak relationship with soil $\mathrm{pH}$ values. During laboratory incubation measurements, there might have been microsites in the soil samples with a soil $\mathrm{pH}$ different from the measured mean $\mathrm{pH}$, indicating that nitrification occurred in microsites having $\mathrm{pH}$ higher than the surrounding soil ()(Paavolainen and Smolander, 1998). That could also be a reason for the relatively high $\mathrm{NO}$ emission despite of the low $\mathrm{pH}$ values. A $\mathrm{pH}$ value between 7 and 8 is ideal for nitrification. However, Paavolainen and Smolander ()(1998) reported coniferous soils that exhibited acid-tolerant nitrification. In this respect, a series of studies reported relationships between NO exchange processes and soil pH (Gödde and Conrad, 2000; Venterea et al., 2004; Nägele and Conrad, 1990b). There is also an enhanced chemical NO production from nitrite at low soil pH (Cleemput and Baert, 1984), which can happen even if nitrite does not accumulate to detectable amounts. In contrast, other studies found no strong relationships between NO exchange and soil pH (Dunfield and Knowles, 1998).

\subsection{Influence of the understory type on net potential NO flux}

A number of studies have detected effects of vegetation on NO emissions (Meixner et al., 1997; Feig et al., 2008; Davidson, 1991; Martin and Asner, 2005; Pilegaard et al., 1999). Our study suggests a strong relationship between understory type and the amount of net potential NO flux. As this relationship can hardly be explained by the measured physical and chemical soil parameters alone, it may originate from the complex biological interactions between plants and their soil environment. Because plant species differ in quantity 
and quality of resources that they return to soil,individual plant species may have important effects on componentsof the soil biota and the processes that they regulate (Wardle et al., 2004). Carbon derived from plant litter mainly influences the decomposer communities. In addition, providing carbon to the rhizosphere creates a hot spot for microbial activity in the soil. For example the size and the density of the nitrifier and denitrifier communities are strongly influenced by plant roots (Philippot et al., 2009).

In our experiments, soils were sieved through a $16 \mathrm{~mm}$ sieve and kept at $4{ }^{\circ} \mathrm{C}$ for up to 2 months. Sieving may have removed the majority of roots but it cannot be excluded that fine roots passed the meshes resulting in a soil sample containing litter, roots, rhizosphere and root free soil. Stöhr and Ullrich (2002), and Stöhr and Stremlau (2006) demonstrated that roots can generate NO. The contribution of living roots to the observed net potential NO fluxes in our experiments should be rather low because most fine roots were removed by sieving. However, biochemical reactions of intact fine roots of spruce when stored in soil at $4{ }^{\circ} \mathrm{C}$ are unchanged for up to 4 weeks and then slowly decline (Pritsch, unpublished results). Thus it cannot be excluded that a minor part of the observed $\mathrm{NO}$ emissions came directly from those fine roots that were not removed by sieving.

A more likely explanation for the different net potential NO fluxes is that litter type and the influence of root exudates influenced functions of the soil microbial communities under the respective understory plants. Rhizosphere effects i.e. the influence of roots on NO emission rates was found by Slemr and Seiler (1991). Vos et al. (1994) measured 2 to 12-fold higher $\mathrm{NO}$ emissions from plots covered with green manure than from fallow plots, probably caused by increased microbial activity in the rhizosphere of the green manure plots compared to the bare soil. Unfortunately, no field studies exist examining the influence of plant roots on NO emissions. A few studies have shown a strong influence of roots on nitrous oxide emissions (Mosier et al., 1990) and it is generally accepted that denitrification is highest in the rhizosphere and decreases with distance from plant roots (Smith and Tiedje, 1979).

According to our study, net potential NO fluxes as well as NO production rates, NO consumption coefficients, and net NO release rates displayed the highest values for soil samples taken under spruce and blueberry covered soils and the lowest values for soil samples taken under moss and grass covered soils. Our results on small net potential NO fluxes from soils taken under moss cover are in accordance with findings of Pilegaard et al. (1999). They suspected that mosses retain nutrients from throughfall but also hypothesized that moss cover simply reflects other factors such as canopy density and water availability. Similarly small net potential NO fluxes were found for soil samples collected under grass cover in our study. Deschampsia flexuosa has a high potential to take up nitrogen in various forms and in competition to microbes (Harrison et al., 2008). This may explain a possibly reduced potential of its microbial communities in nitrogen cycling. The role of its arbuscular mycorrhizal (AM) associates has not been studied at the field site but colonisation by AM seems to be low on acidic soils (Göransson et al., 2008). Inferior competition of microbial communities under moss and grass cover therefore could explain low NO emissions.

Soils taken under blueberry and spruce cover, in contrast, produced high net potential NO fluxes. Both plant species are associated with asco- and basidiomycetes forming ericoid mycorrhizae (blueberry), respectively ectomycorrhizae (spruce). NO accumulation can occur in mycorrhizal symbioses (Stöhr and Stremlau, 2006). Wallenda et al. (2000) also demonstrated that intact mycorrhizal roots of Norway spruce took up substantial amounts of $\mathrm{NH}_{4}^{+}$. This $\mathrm{NH}_{4}^{+}$may act as precursor of nitrification. During nitrification NO can be released as an intermediate. However, due to the fact that only very few roots may have been present and in an active state NO released from mycorrhizae may be of minor relevance. The 10 fold higher NO fluxes from the soils beneath spruce and blueberry are difficult to explain from our data. One factor may be that both plants produce litter types rich in lignin and phenolics (Adamczyk et al., 2008). Tannins formed in degradation of these litter types can form complexes with proteins. Protein phenol complexes can be degraded by ericoid mycorrhizal fungi and saprotrophic fungi but not by ectomycorrhizal fungi (Wu et al., 2003). It has been suggested that relatively more dissolved organic nitrogen (DON) compared to inorganic nitrogen is released upon degradation of these phenol rich litters (cf. from (HoflandZijlstra and Berendse, 2010). Since DON as a possible substrate for nitrification and $\mathrm{N}$-mineralisation has not been measured in our study it can only be speculated if nitrogen sources other than $\mathrm{NH}_{4}^{+}$could explain the high $\mathrm{NO}$ net release or which part of the soil microflora may have contributed to the results. It could be speculated that fungi as decomposers may have played a role in this process. In a beech forest, measurements of nitrous oxide $\left(\mathrm{N}_{2} \mathrm{O}\right)$ emission from forest floor samples indicated that net $\mathrm{N}_{2} \mathrm{O}$ production was the result of predominantly fungal $\mathrm{N}_{2} \mathrm{O}$ production and predominantly bacterial $\mathrm{N}_{2} \mathrm{O}$ consumption (Blagodatskaya et al., 2010).

Altogether our results indicate a challenging field for unravelling the underlying processes of different understory plants on NO net release from forest soils.

\section{Conclusion}

In this study, we investigated the net potential NO fluxes from soil samples of the organic layers of a spruce forest soil covered with four different understory types (moss, grass, spruce and blueberry).

Observed net NO release rates of soil samples taken under moss and grass cover indicated a high potential for NO consumption, resulting in very low net potential NO fluxes 
from soil samples taken under these understory types. In strong contrast, soil samples taken under spruce and blueberry cover showed 10 fold higher net potential NO fluxes, than those taken under moss and grass cover.

Therefore, it is an important lesson of this study, that more attention must be paid to small scale heterogeneity of understory vegetation, when quantification of the biogenic NO emission from a (spruce) forest floor is attempted.

Analysis of the compensation point mixing ratios indicated that measured ambient mixing ratios of $\mathrm{NO}$ at $0.5 \mathrm{~cm}$ above the forest floor of the field site were - even for the soil samples taken under moss and grass cover - too low to change the soil NO flux from upward to downward directions.

Further research investigating effective soil diffusion coefficients is very desirable. The net potential NO flux calculated with the diffusion coefficient according to Millington (1959) is 1.26 fold higher than the net potential NO flux calculated with diffusion coefficients according to Millington and Quirk (1960). Also the position of the optimum NO flux shifts depending on the choice of the diffusion coefficient.

While the understory type seems to be an important variable controlling NO exchange processes, corresponding soil nutrients played generally a less important role. The only exception was for $\mathrm{NH}_{4}^{+}$, the precursor of $\mathrm{NO}_{3}^{-}$in the nitrification process. This implies that nitrification was the limiting factor of NO production for the investigated soils, whereas denitrification played an obviously smaller role. It is remarkable that high NO emissions were observed for soils under woody understory types; this may be related to soil chemical processes in the vicinity of mycorrhized roots, but further studies are certainly necessary for confirmation. As the establishment of different understory types is related to the availability of light at the forest floor as a result of forest thinning, management practises are likely to have important consequences on the net soil $\mathrm{NO}$ emission from a forested site.

Coniferous forest soils in temperate humid climates are characterized by thick organic layers of moder or raw humus forms. Organic layers of our soils had a much higher potential (over 2.5 fold) for $\mathrm{NO}$ emission than the corresponding mineral soil layers. Hence quantification of net potential NO fluxes of the $\mathrm{O}$ horizons of temperate forest soils is an important step for (a) comparison of laboratory and field measurements, (b) up-scaling from laboratory to field scale fluxes (by areal information on understory distribution), and (c) extrapolation from field site results to larger scales (e.g. regional).

Acknowledgements. The authors gratefully acknowledge financial support by the German Science Foundation (DFG project: EGER - "ExchanGE processes in mountainous Regions" (ME 2100-4)) and by the Max Planck Society. Thomas Behrendt is thanked for collecting the soil samples. Particle density analyses were performed at the Landesamt für Geologie und Bergbau in Mainz, Germany. Soil $\mathrm{NO}_{3}^{-}$, soil $\mathrm{NH}_{4}^{+}$, and soil $\mathrm{pH}$ were analysed through Bayreuth Center of Ecology and Environmental Research
(BayCEER), University Bayreuth, Germany. $\mathrm{C}_{\text {org }}$ and $\mathrm{C} / \mathrm{N}$ ratio were analysed through the laboratory of the Institute of Geography, University of Mainz, Germany.

The service charges for this open access publication have been covered by the Max Planck Society.

Edited by: K. Küsel

\section{References}

Adamczyk, B., Kitunen, V., and Smolander, A.: Protein precipitation by tannins in soil organic horizon and vegetation in relation to tree species, Biol. Fert. Soil., 45, 55-64, doi:10.1007/s00374008-0308-0, 2008.

Baumgärtner, M. and Conrad, R.: Effects of soil variables and season on the production and consumption of nitric oxide in oxic soils, Biol. Fert. Soil., 14, 166-174, 1992.

Behrendt, T.: A small-scale geostatistical analysis of the variability of soil properties driving the biogenic emission of nitric oxide from soil, MSc thesis, Geography, Johannes Gutenberg University Mainz, Mainz, Germany, 2009.

Blagodatskaya, E., Dannenmann, M., Gasche, R., and ButterbachBahl, K.: Microclimate and forest management alter fungal-tobacterial ratio and $\mathrm{N}_{2} \mathrm{O}$-emission during rewetting in the forest floor and mineral soil of mountainous beech forests, Biogeochemistry, 97, 55-70, 2010.

Bollmann, A. and Conrad, R.: Influence of $\mathrm{O}_{2}$ availability on $\mathrm{NO}$ and $\mathrm{N}_{2} \mathrm{O}$ release by nitrification and denitrification in soils, Global Change Biol., 4, 387-396, 1998.

Bollmann, A., Koschorreck, M., Meuser, K., and Conrad, R.: Comparison of two different methods to measure nitric oxide turnover in soils, Biol Fert Soils, 29, 104-110, 1999.

Butterbach-Bahl, K., Gasche, R., Breuer, L., and Papen, H.: Fluxes of $\mathrm{NO}$ and $\mathrm{N}_{2} \mathrm{O}$ from temperate forest soils: Impact of forest type, $\mathrm{N}$ deposition and of liming on the $\mathrm{NO}$ and $\mathrm{N}_{2} \mathrm{O}$ emissions, Nutr. Cycl. Agroecosys., 48, 79-90, 1997.

Butterbach-Bahl, K., Stange, F., and Papen, H.: Regional inventory of nitric oxide and nitrous oxide emissions for forest soils of southeast Germany using the biogeochmical model Pnet-nDNDC, J. Geophys. Res., 106, 34155-34166, 2001.

Butterbach-Bahl, K., Rothe, A., and Papen, H.: Effect of tree distance on $\mathrm{N}_{2} \mathrm{O}$ and $\mathrm{CH}_{4}$-fluxes from soils in temperate forest ecosystems, Plant. Soil., 240, 91-103, 2002.

Cleemput, O. and Baert, L.: Nitrite: A key compound in $\mathrm{n}$ loss processes under acid conditions?, Plant. Soil., 76, 233-241, 1984.

Conrad, R.: Compensation concentration as critical variable for regulating the flux of trace gases between soil and atmosphere, Biogeochemistry, 27, 155-170, 1994.

Crutzen, P. J.: Role of $\mathrm{NO}$ and $\mathrm{NO}_{2}$ in the chemistry of the troposphere and stratosphere, Ann. Rev. Earth Planet Sci., 7, 443-472, 1979.

Davidson, E. A.: Fluxes of nitrous oxide and nitric oxide from terrestrial ecosystems, in: Microbial production and consumption of greenhouse gases: Methane, nitrogen oxides, and halomethanes, edited by: Rogers, J. E., and Whitman, W. B., American Society for Microbiology, Washington DC, USA, 219-235, 1991.

Davidson, E. A., Matson, P. A., Vitousek, P. M., Riley, R., Dunkin, K., Garcia-Mendez, G., and Maass, J. M.: Processes regulating 
soil emissions of $\mathrm{NO}$ and $\mathrm{N}_{2} \mathrm{O}$ in a seasonally dry tropical forest, Ecology, 74, 130-139, 1993.

Davidson, E. A. and Kingerlee, W.: A global inventory of nitric oxide emissions from soils, Nutr. Cycl. Agroecosys., 48, 37-50, 1997.

Davidson, E. A., Janssens, I. A., and Luo, Y.: On the variability of respiration in terrestrial ecosystemy: Moving beyond $Q_{10}$, Global Change Biol., 12, 154-164, 2006.

Denman, K. L., Brasseur, G. P., Chidthaisong, A., Ciais, P., Cox, P. M., Dickinson, R. E., Hauglustaine, D., Heinze, C., Holland, E. A., Jacob, D. J., Lohmann, U., Ramachandran, S., da Silva Dias, P. L., Wofsy, S. C., and Zhang, X.: Couplings between changes in the climate system and boigeochemistry, in: Climate Change 2007: The physical science basis. contribution of working group 1 to the fourth assesment report of the Intergovernmental Panel on Climate Change, edited by: Solomon, S., Qin, D., Manning, M., Chen, Z., Marquis, M., Averyt, K. B., Tignor, M., and Miller, H. L., University Press Cambridge, 2007.

Dunfield, P. F. and Knowles, R.: Organic matter, heterotrophic activity, and NO consumption in soils, Global Change Biol., 4, 199-207, 1998.

Falge, E., Tenhunen, J. D., and Aubinet, M.: A model-based study of carbon fluxes at ten European forest sites, in: Fluxes of carbon, water and energy of European forests edited by: Valentini, R., Springer, Berlin, 151-177, 2003.

Feig, G. T., Mamtimin, B., and Meixner, F. X.: Soil biogenic emissions of nitric oxide from a semi-arid savanna in south Africa, Biogeosciences, 5, 1723-1738, 2008, http://www.biogeosciences.net/5/1723/2008/.

Firestone, M. K., and Davidson, E. A.: Microbiological basis of NO and $\mathrm{N}_{2} \mathrm{O}$ production and consumption in soil in: Exchange of trace gases between terrestrial ecosystems and the atmosphere, edited by: Andreae, M. O., and Schimel, D. S., Wiley, Chichester, UK, 7-21, 1989.

Foken, T.: Lufthygienisch-biologische Kennzeichnung des oberen Egertales (Fichtelbegirge bis Karlovy vary), Bayreuther Forum Ökologie 100, 1-70, 2003.

Fowler, D., Pilegaard, K., Sutton, M. A., Ambus, P., Raivonen, M., Duyzer, J., Simpson, D., Fagerli, H., Fuzzi, S., Schjoerring, J. K., Granier, C., Neftel, A., Isaksen, I. S. A., Laj, P., Maione, M., Monks, P. S., Burkhardt, J., Daemmgen, U., Neirynck, J., Personne, E., Wichink-Kruit, R., Butterbach-Bahl, K., Flechard, C., Tuovinen, J. P., Coyle, M., Gerosa, G., Loubet, B., Altimir, N., Gruenhage, L., Ammann, C., Cieslik, S., Paoletti, E., Mikkelsen, T. N., Ro-Poulsen, H., Cellier, P., Cape, J. N., Horváth, L., Loreto, F., Niinemets, Ü., Palmer, P. I., Rinne, J., Misztal, P., Nemitz, E., Nilsson, D., Pryor, S., Gallagher, M. W., Vesala, T., Skiba, U., Brüggemann, N., Zechmeister-Boltenstern, S., Williams, J., O’Dowd, C., Facchini, M. C., de Leeuw, G., Flossman, A., Chaumerliac, N., and Erisman, J. W.: Atmospheric composition change: Ecosystems-atmosphere interactions, Atmos. Environ., 43, 5193-5267, 2009.

Galbally, I. E.: Factors controlling $\mathrm{NO}_{\mathrm{x}}$ emissions from soils, in: Exchange of trace gases between terrestrial ecosystems and the atmosphere, edited by: Andreae, M. O., and Schimel, D. S., Wiley \& Sons, Chichester, UK, 23-37, 1989.

Galbally, I. E. and Johansson, C.: A model relating laboratory measurements of rates of nitric-oxide production and fieldmeasurements of nitric-oxide emission from soils, J. Geophys.
Res.-Atmos., 94, 6473-6480, 1989.

Gasche, R. and Papen, H.: A 3-year continuous record of nitrogen trace gas fluxes from untreated and limed soil of a $\mathrm{N}$-saturated spruce and beech forest ecosystem in Germany 2. $\mathrm{NO}$ and $\mathrm{NO}_{2}$ fluxes, J. Geophys. Res., 104, 505-520, 1999.

Gasche, R. and Papen, H.: Spatial variability of $\mathrm{NO}$ and $\mathrm{NO}_{2}$ flux rates from soil of spruce and beech forest ecosystems, Plant. Soil., 240, 67-76, 2002.

Gelfand, I., Feig, G., Meixner, F. X., and Yakir, D.: Afforestation of semi-arid shrubland reduces biogenic NO emission from soil, Soil Biol. Biochem., 41, 1561-1570, 2009.

Gerstenberger, P., Foken, T., and Kalbitz, K.: The lehstenbach and steinkreuz catchment in NE Bavaria, Germany, in: Biogeochemistry of forested catchments in a changing environment: A german case study, edited by: Matzner, E., Springer, Berlin, Germany, 15-44, 2004.

Gödde, M. and Conrad, R.: Influence of soil properties on the turnover of nitric oxide and nitrous oxide by nitrification and denitrification at constant temperature and moisture, Biol. Fert. Soil., 32, 120-128, 2000.

Göransson, P., Olsson, P. A., Postma, J., and Falkengren-Grerup, U.: Colonisation by arbuscular mycorrhizal and fine endophytic fungi in four woodland grasses - variation in relation to $\mathrm{pH}$ and aluminium, Soil Biol. \& Biochem., 40, 2260-2265, doi:10.1016/j.soilbio.2008.05.002, 2008.

Guthrie, T. F. and Duxbury, J. M.: Nitrogen mineralization and denitrification in organic soil, Soil. Sci. Soc. Am. J., 42, 908-912, 1978.

Harrison, K. A., Bol, R., and Bardgett, R. D.: Do plant species with different growth strategies vary in their ability to compete with soil microbes for chemical forms of nitrogen?, Soil Biology \& Biochemistry, 40, 228-237, 10.1016/j.soilbio.2007.08.004, 2008.

Hofland-Zijlstra, J. D. and Berendse, F.: Effects of litters with different concentrations of phenolics on the competition between calluna vulgaris and deschampsia flexuosa, Plant. Soil., 327, 131-141, doi:10.1007/s11104-009-0037-7, 2010.

Horváth, L., Führer, E., and Lajtha, K.: Nitric oxide and nitrous oxide emission from Hungarian forest soils; linked with atmospheric N-deposition, Atmos. Environ., 40, 7786-7795, 2006.

Jambert, C., Delmas, R. A., Labroue, L., and Chassin, P.: Nitrogen compound emissions from fertilized soils in a maize field pine tree forest agrosystem in the southwest of France, J. Geophys. Res.-Atmos., 99, 16523-16530, 1994.

Johansson, C.: Field measurements of emission of nitric oxide from fertilized and unfertilized forest soils in Sweden, J. Atmos. Chem., 1, 429-442, 1984.

Johansson, C. and Granat, L.: Emission of nitric oxide from arable land, Tellus, 36B, 25-37, 1984.

Kapiluto, Y., Yakir, D., Tans, P., and Berkowitz, B.: Experimental and numerical studies of the $\mathrm{O}-18$ exchange between $\mathrm{CO}_{2}$ and water in the atmosphere-soil invasion flux, Geochim. Cosmochim. Acta, 71, 2657-2671, 2007.

Kesik, M., Ambus, P., Baritz, R., Bruggemann, N. B., ButterbachBahl, K., Damm, M., Duyzer, J., Horvath, L., Kiese, R., Kitzler, B., Leip, A., Li, C., Pihlatie, M., Pilegaard, K., Seufert, G., Simpson, D., Skiba, U., Smiatek, G., Vesala, T., and ZechmeisterBoltenstern, S.: Inventories of $\mathrm{N}_{2} \mathrm{O}$ and $\mathrm{NO}$ emissions from $\mathrm{Eu}-$ ropean forest soils, Biogeosciences, 2, 353-375, 2005, http://www.biogeosciences.net/2/353/2005/. 
Kirkman, G. A., Gut, A., Ammann, C., Gatti, L. V., Cordova, A. M., Moura, M. A. L., Andreae, M. O., and Meixner, F. X.: Surface exchange of nitric oxide, nitrogen dioxide, and ozone at a cattle pasture in rondonia, Brazil, J. Geophys. Res.-Atmos., 107, 8083, doi:10.1029/2001JD000523, 2002.

Kirschbaum, M. U. F.: The temperature dependence of soil organic matter decomposition, and the effect of global warming on soil organic C storage, Soil. Biol. Biochem., 27, 753-760, 1995.

Kitzler, B., Zechmeister-Boltenstern, S., Holtermann, C., Skiba, U., and Butterbach-Bah, K.: Controls over $\mathrm{N}_{2} \mathrm{O}, \mathrm{NO}_{\mathrm{x}}$ and $\mathrm{CO}_{2}$ fluxes in a calcareous mountain forest soil, Biogeosciences, 3 , 383-395, 2006, http://www.biogeosciences.net/3/383/2006/.

Koponen, H. T., Escudé Duran, C., Maljanen, M., Hytönen, J., and Martikainen, P. J.: Temperature responses of $\mathrm{NO}$ and $\mathrm{N}_{2} \mathrm{O}$ emissions from boreal organic soil, Soil Biol. Biochem., 38, 17791787, 2006.

Koschorreck, M. and Conrad, R.: Kinetics of nitric oxide consumption in tropical soils under oxic and anoxic conditions, Biol. Fert. Soil., 25, 82-88, 1997.

Laville, P., Flura, D., Gabrielle, B., Loubet, B., Fanucci, O., Rolland, M. N., and Cellier, P.: Characterisation of soil emissions of nitric oxide at field and laboratory scale using high resolution method, Atmos. Environ., 43, 2648-2658, 2009.

Lehmann, L.: Untersuchungen zu biogenen NO-Emissionen aus einem mitteleuropäischen Laubwaldboden, Msc thesis, Department of Geography and Geoecology, University of Kalsruhe, Karlsruhe, Germany, 92 pp., 2002.

Ludwig, J., Meixner, F., Vogel, B., and Förstner, J.: Soil-air exchange of nitric oxide: An overview of processes, environmental factors, and modeling studies, Biogeochemistry, 52, 225-257, 2001.

Martin, R. and Asner, G.: Regional estimate of nitric oxide emissions following woody encroachment: Linking imaging spectroscopy and field studies, Ecosystems, 8, 33-47, 2005.

Meixner, F. X.: Surface exchange of odd nitrogen oxides, Nova Acta Leopoldina NF, 70, 299-348, 1994.

Meixner, F. X., Fickinger, T., Marufu, L., Serça, D., Nathaus, F. J., Makina, E., Mukurumbira, L., and Andreae, M. O.: Preliminary results on nitric oxide emission from a southern African savanna ecosystem, Nutr Cycl Agroecosys, 48, 123-138, 1997.

Meixner, F. X. and Yang, W.: Biogenic emissions of nitric oxide and nitrous oxide from arid and semi-arid land, in: Dryland ecohydrology, edited by: D’Odoricoand, P., and Porporat, A., Springer, Dordrecht, The Netherlands, 233-255, 2006.

Michel, K., Matzner, E., Dignac, M.-F., and Kögel-Knabner, I.: Properties of dissolved organic matter related to soil organic matter quality and nitrogen additions in Norway spruce forest floors, Geoderma, 130, 250-264, 2006.

Millington, R. J.: Gas diffusion in porous media, Science, 130, 100$102,1959$.

Millington, R. J. and Quirk, J. P.: Transport in porous media [in soil science], Trans. Int. Congr. Soil. Sci., 7, 97-106, 1960.

Moldrup, P., Olesen, T., Gamst, J., Schjonning, P., Yamaguchi, T., and Rolston, D. E.: Predicting the gas diffiusion coefficent in repacked soil: Water-induced linear reduction model, Soil Sci. Soc. Am. J., 64, 1588-1594, 2000.

Moravek, A.: Vertical distribution of reactive and non-reactive trace gases in and above a spruce canopy, MSc thesis, Department of Bauingeneur-, Geo- and Umweltwissenschaften, University of
Karlsruhe, Karlsruhe, Germany, 126 pp., 2008.

Mosier, A. R., Mohanty, S. K., Bhadrachalam, A., and Chakravorti, S. P.: Evolution of dinitrogen and nitrous oxide from the soil to the atmosphere through rice plants, Biol. Fert. Soil., 9, 61-67, 1990.

Muhr, J., Goldberg, S. D., Borken, W., and Gebauer, G.: Repeated drying-rewetting cycles and their effects on the emission of $\mathrm{CO}_{2}$, $\mathrm{N}_{2} \mathrm{O}, \mathrm{NO}$, and $\mathrm{CH}_{4}$ in a forest soil, J. Plant. Nutr. Soil. Sci., 171, 719-728, 2008.

Nägele, W. and Conrad, R.: Influence of $\mathrm{pH}$ on the release of NO and $\mathrm{N}_{2} \mathrm{O}$ from fertilized and unfertilized soil, Biol. Fert. Soil., 10, 139-144, 1990a.

Nägele, W. and Conrad, R.: Influence of soil $\mathrm{pH}$ on the nitratereducing microbial populations and their potential to reduce nitrate to NO and $\mathrm{N}_{2} \mathrm{O}$, FEMS Microbiol. Lett., 74, 49-57, 1990b.

Nishina, K., Takenaka, C., and Ishizuka, S.: Spatial variations in nitrous oxide and nitric oxide emission potential on a slope of Japanese cedar (cryptomeria japonica) forest, Soil. Sci. Plant. Nutr., 55, 179-189, 2009.

Oberdorfer, E.: Pflanzensoziologische Exkursionsflora, Ulmer, Stuttgart, Germany, 1050 pp., 1994.

Olive, D. J.: Prediction intervals for regression models, Comp. Stat. Data An., 51, 3115-3122, 2007.

Ormeci, B., Sanin, S. L., and Peirde, J. J.: Laboratory study of NO flux from agricultural soil: Effects of soil moisture, $\mathrm{pH}$, and temperature, J. Geophys. Res., 104, 1621-1629, 1999.

Otter, L. B., Yang, W. X., Scholes, M. C., and Meixner, F. X.: Nitric oxide emissions from a southern African savanna, J. Geophys. Res.-Atmos., 104, 18471-18485, 1999.

Paavolainen, L. and Smolander, A.: Nitrification and denitrification in soil from: A clear-cut Norway spruce (picea abies) stand, Soil. Biol. Biochem., 30, 775-781, 1998.

Papke, H. and Papen, H.: Influence of acid rain and liming on fluxes of $\mathrm{NO}$ and $\mathrm{NO}_{2}$ from forest soil, Plant. Soil., 199, 131-139, 1998.

Philippot, L., Hallin, S., Borjesson, G., and Baggs, E. M.: Biochemical cycling in the rhizosphere having an impact on global change, Plant. Soil., 321, 61-81, 2009.

Pilegaard, K., Hummelshoj, P., and Jensen, N. O.: Nitric oxide emission from a Norway spruce forest floor, J. Geophys. Res.Atmos., 104, 3433-3445, 1999.

Pilegaard, K., Skiba, U., Ambus, P., Beier, C., Bruggemann, N., Butterbach-Bahl, K., Dick, J., Dorsey, J., Duyzer, J., Gallagher, M., Gasche, R., Horvath, L., Kitzler, B., Leip, A., Pihlatie, M. K., Rosenkranz, P., Seufert, G., Vesala, T., Westrate, H., and Zechmeister-Boltenstern, S.: Factors controlling regional differences in forest soil emission of nitrogen oxides ( $\mathrm{NO}$ and $\mathrm{N}_{2} \mathrm{O}$ ), Biogeosciences, 3, 651-661, 2006, http://www.biogeosciences.net/3/651/2006/.

Plake, D.: Vertikale Konzentrationsprofile und Flüsse von reaktiven und nicht reaktiven Spurengasen im Fichtelgebirge, MSc thesis, Landscapeecology, Westfälische Wilhelms-University Münster, Münster, Germany, 168 pp., 2009.

Remde, A., Slemr, F., and Conrad, R.: Microbial-production and uptake of nitric-oxide in soil, FEMS Microbiol. Ecol., 62, 221230, 1989.

Remde, A., Ludwig, J., Meixner, F. X., and Conrad, R.: A study to explain the emission of nitric-oxide from a marsh soil, J. Atmos. Chem., 17, 249-275, 1993. 
Rudolph, J. and Conrad, R.: Flux between soil and atmosphere, vertical concentration profiles in soil, and turnover of nitric oxide: 2 . Experiments with naturally layered soil cores, J. Atmos. Chem., 23, 275-300, 1996.

Scheffer, F., and Schachtschabel, P.: Lehrbuch der Bodenkunde, Spektrum, Berlin, Germany, 593 pp., 2002.

Schindlbacher, A., Zechmeister-Boltenstern, S., and ButterbachBahl, K.: Effects of soil moisture and temperature on $\mathrm{NO}, \mathrm{NO}_{2}$, and $\mathrm{N}_{2} \mathrm{O}$ emissions from European forest soils, J. Geophys. Res., 109, D17302, doi:10.1029/2004JD004590, 2004.

Schmitt, A., Glaser, B., Borken, W., and Matzner, E.: Repeated freeze-thaw cycles changed organic matter quality in a temperate forest soil, J. Plant. Nutr. Soil. Sci., 171, 707-718, 2008.

Skiba, U., Fowler, D., and Smith, K.: Emissions of $\mathrm{NO}$ and $\mathrm{N}_{2} \mathrm{O}$ from soils, Environ. Monit. Assess., 31, 153-158, 1994.

Skiba, U., Fowler, D., and Smith, K. A.: Nitric oxide emissions from agricultural soils in temperate and tropical climates: Sources, controls and mitigation options, Nutr. Cycl. Agroecosys., 48, 139-153, 1997.

Skopp, J., Jawson, M. D., and Doran, J. W.: Steady-state aerobic microbial activity as a function of soil water content, Soil. Sci. Soc. Am. J., 54, 1619-1625, 1990.

Slemr, F. and Seiler, W.: Field study of environmental variables controlling the $\mathrm{NO}$ emissions from soil and the NO compensation point, J. Geophys. Res., 96, 13017-13031, 1991.

Smith, K. A., Ball, T., Conen, F., Dobbie, K. E., Massheder, J., and Rey, A.: Exchange of greenhouse gases between soil and atmosphere: Interactions of soil physical factors and biological processes, Eur. J. Soil. Sci., 54, 779-791, 2003.

Smith, M. S. and Tiedje, J. M.: The effect of roots on soil denitrification, Soil. Sci. Soc. Am. J., 43, 951-955, 1979.

Stöhr, C. and Ullrich, W. R.: Generation and possible roles of NO in plant roots and their apoplastic space, J. Exp. Bot., 53, 2293 2303, 2002.

Stöhr, C. and Stremlau, S.: Formation and possible roles of nitric oxide in plant roots, J. Exp. Bot., 57, 463-470, 2006.

Subke, J.-A., Reichstein, M., and Tenhunen, J. D.: Explaining temporal variation in soil $\mathrm{CO}_{2}$ efflux in a mature spruce forest in southern Germany, Soil. Biol. Biochem., 35, 1467-1483, 2003.

van Dijk, S. M. and Meixner, F. X.: Production and consumtion of $\mathrm{NO}$ in forest and pasture soils from the Amazon basin, Water Air Soil Poll., 1, 119-130, 2001. van Dijk, S. M., Gut, A., Kirkman, G. A., Meixner, F. X., Andreae, M. O., and Gomes, B. M.: Biogenic NO emissions from forest and pasture soils: Relating laboratory studies to field measurements, J. Geophys. Res.-Atmos., 107, 8058, doi:10.1029/2001JD000358, 2002.

Venterea, R. T. and Rolston, D. E.: Mechanisms and kinetics of nitric nitrous oxide production during nitrification in agricultural soil, Global Change Biol., 6, 303-316, 2000.

Venterea, R. T., Groffman, P. M., Castro, M. S., Verchot, L. V., Fernandez, I. J., and Adams, M. B.: Soil emissions of nitric oxide in two forest watersheds subjected to elevated $\mathrm{n}$ inputs, Forest Evol. Manage., 196, 335-349, 2004.

Venterea, R. T., Rolston, D. E., and Cardon, Z. G.: Effects of soil moisture, physical, and chemical characteristics on abiotic nitric oxide production, Nutr. Cy. Agroecosyst., 72, 27-40, 2005.

Vos, G., Bergevoet, I., Védy, J., and Neyroud, J.: The fate of spring applied fertilizer $\mathrm{N}$ during the autumn-winter period: Comparison between winter-fallow and green manure cropped soil, Plant. Soil., 160, 201-213, 1994.

Wallenda, T., Stober, C., Högbom, L., Schinkel, H., George, E., Högberg, P., and Read, D. J.: Nitrogen uptake processes in roots and mycorrhizas, in: Carbon and nitrogen cycling in European forest ecosystems, edited by: Schulze, E. D., Springer, Heidelberg, Germany, 21, 122-143, 2000.

Wardle, D. A., Bardgett, R. D., Klironomos, J. N., Setälä, H., van der Putten, W. H., and Wall, D. H.: Ecological linkages between aboveground and belowground biota, Science, 304, 1629-1633, doi:10.1126/science.1094875, 2004.

Wu, T., Sharda, J. N., and Koide, R. T.: Exploring interactions between saprotrophic microbes and ectomycorrhizal fungi using a protein-tannin comples as an $\mathrm{n}$ source by red pine (pinus resinosa), New Phytol., 159, 131-139, 2003.

Yu, J. B., Meixner, F. X., Sun, W. D., Liang, Z. W., Chen, Y., Mamtimin, B., Wang, G. P., and Sun, Z. G.: Biogenic nitric oxide emission from saline sodic soils in a semiarid region, northeastern China: A laboratory study, J. Geophys. Res., 113, D07111, doi:10.1029/2006JD008025, 2008.

Zheng, X. H., Huang, Y., Wang, Y. S., Wang, M. X., Jin, J. S., and Li, L. T.: Effects of soil temperature on nitric oxide emission from a typical chinese rice-wheat rotation during the nonwaterlogged period, Global Change Biol., 9, 601-611, 2003. 